\title{
THE SULFUR BUDGET AND SULFUR ISOTOPIC COMPOSITION OF MARTIAN REGOLITH BRECCIA NWA 7533
}

Jean-Pierre LORAND ${ }^{1}$, Jabrane LABIDI ${ }^{2,3,4}$, Claire ROLLION-BARD ${ }^{4}$, Emilie THOMASSOT ${ }^{5}$, Jeremy J. BELLUCCI $^{6}$, Martin WHITEHOUSE ${ }^{7}$, Alexander NEMCHIN ${ }^{6}$, Munir HUMAYUN ${ }^{8}$, James FARQUHAR ${ }^{3}$, Roger H. HEWINS ${ }^{9,10}$, Brigitte ZANDA $^{9}$, Sylvain PONT $^{9}$

${ }^{1}$ Laboratoire de Planétologie et Géodynamique à Nantes, CNRS UMR 6112,Université de Nantes, 2 Rue de la Houssinère, BP 92208, 44322 Nantes Cédex 3, France. (jean-pierre.lorand@univ-nantes.fr)

${ }^{2}$ Geophysical Laboratory, Carnegie Institution of Washington, Washington, D.C. 20015, USA (jlabidi@carnegiescience.edu)

${ }^{3}$ Department of Geology, University of Maryland, College Park MD, 20740, USA

${ }^{4}$ Université de Paris, Institut de physique du globe de Paris, CNRS, F-75005 Paris, France (rollion@ipgp.fr)

${ }^{5}$ CRPG-CNRS, Nancy, France (emilie.@crpg.cnrs-nancy.fr);

${ }^{6}$ Dept. of Applied Geology, Curtin University, Perth, WA 6845, Australia (jeremy.belluci@gmail.com; A. Nemchin@curtin.edu.au);

${ }^{7}$ Laboratory for Isotope Geology, Swedish Mus. of Nat History, Stockholm SE-104 05, Sweden (martin.whitehouse@nrm.se)

${ }^{8}$ Department of Earth, Ocean \& Atmospheric Science and National High Magnetic Field Laboratory, Florida State University, Tallahassee, FL 32310, USA (humayun@magnet.fsu.edu)

${ }^{9}$ Institut de Minéralogie, de Physique des Matériaux, et de Cosmochimie (IMPMC) - Sorbonne Université- Muséum National d'Histoire Naturelle, UPMC Université Paris 06, UMR CNRS 7590, IRD UMR 206, 61 rue Buffon, 75005 Paris, France.(hewins@rci.rutgers.edu; zanda@mnhn.fr ; spont@mnhn.fr)

${ }^{10}$ Department of Earth \& Planetary Sciences, Rutgers University, Piscataway, NJ 08854, USA

Corresponding author : jean-pierre.lorand@univ-nantes.fr 
34 Abstract. The sulfur isotope budget of Martian regolith breccia (NWA 7533) has been addressed 35 from conventional fluorination bulk-rock analyses and ion microprobe in-situ analyses. The bulk

\section{INTRODUCTION}

In the absence of ozone, terrestrial sulfur of Archean age exhibits prominent mass independent isotope fractionation (MIF) effects due to $\mathrm{UV}$ irradiation of atmospheric $\mathrm{SO}_{2}$ to form a variety of reduced and oxidized sulfur species (Farquhar et al., 1998; Pavlov and Kasting, 2002; Farquhar et al., 2002). The martian atmosphere is likely to have had similar UV irradiation effects on volcanically produced $\mathrm{SO}_{2}$ over most of martian history, thus producing massindependent fractionation in S isotopic signatures (Farquhar et al., 2000; Halevy et al., 2007; Righter et al., 2009). In contrast to Earth, the martian sulfur cycle may have been dominated throughout its geochemical history by processes operating at the martian surface due to the lack of an efficient sulfur crustal recycling mechanism (Foley et al., 2003; King and McLennan, 1990; Franz et al., 2019 and references therein). Landers, rovers, and remote sensing observations by orbiting spacecraft using different spectrometers identified a great diversity of 
66 Ca-, Mg-, Fe-sulfate minerals as major components of the martian surface (see a review in Franz 67 et al., 2019a). The abundance and diversity of sulfate minerals testify to a wide range of 68 formation processes such as sulfur output through volcanic outgassing of $\mathrm{SO}_{2}$ (Gaillard et al. 69 2009; Tian et al. 2015; Kerber et al. 2015; Franz et al, 2017), oxidation or acid weathering of 70 pre-existing igneous pyrrhotite/pyrite to Fe-sulfates (e.g. Zolotov and Shock, 2005; Dehouck et al., 2012), hydrothermal precipitation (e.g. McCubbin et al., 2009), and brines from low pH waters that contained sulfuric acid (e.g. McLennan et al., 2005), to near neutral, low-salinity water that precipitated Ca sulfates by evaporation (e.g. Grotzinger et al., 2013; Nachon et al., 2014). The Curiosity rover has identified Ca-sulfate-bearing fractures of diagenetic origin deposited from near neutral water in the fluvio-lacustrine sedimentary sequence filling the Noachian Gale Crater (Grotzinger et al., 2013; Nachon et al., 2014). Thick veins of Ca-sulfate (gypsum) were also identified at Endeavour crater by the Opportunity rover (Squyres et al., 2012).

Sulfates of martian origin were also identified in the interior of martian meteorites. The Chassigny meteorite shows Ca-sulfate associated with carbonate veins (Wentworth and Gooding 1994). Nakhlite meteorites show evaporitic Ca-sulfate (gypsum, anhydrite) associated with halite, Fe-rich carbonate, saponite, $\mathrm{Fe}^{3+}$ oxides and silica gels, all well preserved in the Nakhla meteorite (Gooding et al. 1991; Bridges and Grady, 2000). Jarosite was found in a melt inclusion inside clinopyroxene in MIL 03346 nakhlite (McCubbin et al. 2009). These different sulfates point to episodic periods of water flow that exchanged sulfur processed with the atmosphere and then deposited oxidized sulfur-bearing minerals through fractures, millions of years after complete solidification of the igneous mass (Changela and Bridges, 2011; Bridges et al., 2019, and references therein). Sulfates were also assimilated into the nakhlite parent magma at the igneous stage, as shown by isotopically anomalous igneous pyrrhotite (Franz et al., 2014; Dottin et al., 2018; Mari et al., 2019) that reequilibrated its metal-to-sulfur ratios toward metal-deficient compositions (Chevrier et al., 2011; Mari et al., 2019). The nakhlite meteorites which contain both sulfate and magmatic sulfide minerals display the largest range of MIF anomalies (Farquhar et al., 2007b; Franz et al., 2014 ; Dottin et al., 2018). The Lafayette meteorite, another nakhlite contains sulfates and/or sulfides with positive $\Delta^{33} \mathrm{~S}$ anomalies (like the Chassigny meteorite) while Fe sulfides from the 4.1 Ga-old orthopyroxenite ALH 84001 display large variations from negative to positive $\Delta^{33} \mathrm{~S}$ values $(-1.10 \pm 0.14 \%$ to $0.66 \pm 0.22 \%$ ) (Farquhar et al., 2000b; Franz 
97 et al., 2014).

98 Sulfur isotope exchange between oxidized and reduced forms of sulfur during 99 hydrothermal circulation can also generate large mass-dependent fractionations of $\mathrm{S}$ isotopes. 100 Impact-driven hydrothermal activity is thought to explain $\delta^{34} \mathrm{~S}$ of -9 to $-10 \%$ in carbonate101 associated pyrites of the 4.1 Ga-old orthopyroxenite ALH 84001 (Shearer et al., 1996). Franz et 102 al (2017) documented Fe-sulfides strongly depleted in ${ }^{34} \mathrm{~S}\left(\delta^{34} \mathrm{~S}=-47 \pm 14 \%\right.$ ) in the Cumberland 103 (CB) and Oudam (OU) fluvio-lacustrine sediments of Gale Crater. These values were interpreted 104 to be produced by equilibrium isotopic fractionation between sulfides and sulfates in 105 groundwater warmed by impact or igneous intrusions (Franz et al., 2017). Regolith breccia 106 NWA 7533 (paired with the so-called "Black Beauty" meteorite NWA 7034 (Agee et al., 2013) 107 and paired stones) that has sampled 4.4 Ga old impact lithologies (Humayun et al., 2013) is of 108 special interest for testing this suggestion of Franz et al. (2017). Unlike SNC meteorites, regolith 109 breccias are almost devoid of magmatic sulfides and contain sulfides of mostly hydrothermal 110 origin (pyrite and scarce pyrrhotite; Lorand et al., 2015). This Ni-rich (up to 4.5 wt.\% Ni) pyrite 111 is primary unlike other hydrothermal pyrite occurrences so far reported in SNC meteorites and 112 ALH 84001 that are instead the oxidation product of more reduced sulfides (Shearer et al, 1996; 113 Greenwood et al., 2000; Lorand et al., 2018a). This pyrite likely reflects S-rich hydrothermal 114 fluids that percolated through the breccia billions of years after breccia formation (Lorand et al., 115 2015; Goderis et al., 2016).

116 Our aim is to address the origin of $\mathrm{S}$ in the late circulating fluids using the $\mathrm{S}$ budget from 117 both bulk-rock S contents and S multi-isotope systematics. We focus on NWA 7533 because it is 118 the only one among the impact breccia samples that has been studied in detail for pyrite 119 distribution and composition including chalcophile trace elements (Lorand et al., 2015; 2018b).

120 The sulfur isotope analyses were done both with digestion of powdered rocks and by ion 121 microprobe in-situ measurements on pyrite and pyrrhotite. These data are used to build a 122 comprehensive picture of hydrothermal S cycling in this polymict regolith breccia.

123

124

125

126

127

\section{MAIN PETROGRAPHIC FEATURES OF NWA 7533}

The petrogenesis of NWA 7533 impact breccia has been reported in a series of recent papers (Wittmann et al., 2015; McCubbin et al., 2016; Hewins et al., 2017). Its impact origin was 
128 identified from the rock textures (various lithic clasts and impact melt rocks) and high (up to $1291,000 \mathrm{ppm} \mathrm{Ni}, 1<\mathrm{Ir}<100 \mathrm{ppb})$ concentrations of siderophile elements (Ni, Ir and other highly 130 siderophile elements - HSE) (Humayun et al., 2013; Wittmann et al., 2015; Goderis et al., 2016). 131 NWA 7533 meteorite was classified as a polymict breccia because it is composed of separate 132 clasts with chemical compositions that require multiple igneous, sedimentary or impact-melt 133 sources (see Hewins et al., 2017, and references therein).

134 Briefly, its fine-grained Inter-Clast matrix (ICM) contains lithic clasts (norite, 135 monzonite) and single mineral clasts derived from these rocks and probably orthopyroxenite, as 136 well as clast-laden melt rocks (CLMR), microbasalt, and melt spherules. Noritic clasts are 137 composed of ferroan pyroxene $\left(\mathrm{En}_{<72}\right)$, orthopyroxene or inverted pigeonite, plagioclase $\left(\mathrm{An}_{50-30}\right)$ 138 and Cr-rich magnetite. Monzonitic clasts show alkali feldspar, often perthitic, associated with 139 plagioclase $\left(<\mathrm{An}_{30}\right)$, ferroan pyroxene, chlorapatite and Fe-Ti oxides (magnetite, ilmenite and 140 accessory rutile). Noritic and monzonitic clasts contain zircon and baddeleyite that may also 141 occur as individual mineral clasts. Zircons in NWA 7533 and paired meteorites yielded pre142 Noachian, U-Pb crystallization ages of 4.47-4.35 Ga with a discordance implying a disturbance 143 at around 1.4 Ga (Humayun et al., 2013; Bellucci et al., 2015; McCubbin et al., 2016; Bouvier et 144 al., 2018). Crystal clasts are fragments of disaggregated lithic clasts. Noritic and monzonitic 145 clasts show widespread evidence of impactor-derived contamination: their concentration levels 146 of siderophile elements $(\mathrm{Ni}, \mathrm{Ir} . .$.$) indicate that 3-5\% impactor materials accumulated over$ 147 repeated impact events (Humayun et al., 2013). This pervasive siderophile enrichment in the 148 melt rocks suggests a thick sequence of impact-generated rocks including mature regolith. The 149 monzonite clasts were formed by either differentiation of these large impact melt sheets or re150 melting of primary martian crust at depth in the presence of volatiles. A few pyroxene clasts 151 contain exsolution implying prolonged cooling at depth. Another zoned pyroxene population 152 suggests near surface crystallization (Leroux et al., 2016; Hewins et al., 2017 and references 153 therein).

154 Microbasalts and CLMR clasts show closely similar bulk composition and similar 155 siderophile element enrichment (Humayun et al., 2013). CLMRs are composed of plagioclase 156 laths and subophitic pyroxene indicating rapid quenching due to incorporation of abundant 157 clasts. Microbasalts are composed of orthopyroxene $\left(\mathrm{En}_{73-63}\right)$ or pigeonite $\left(\mathrm{En}_{63-49}\right)$, augite $\left(\mathrm{En}_{46-}\right.$ 158 29), plagioclase $\left(\mathrm{An}_{66-30}\right)$ and Fe-rich spinel. Because of their subophitic to granoblastic textures, 
159 microbasalts are interpreted as impact melt that crystallized less rapidly than CLMR (Hewins et 160 al., 2017). Regarding lithophile trace element geochemistry, the spherules, the groundmass of the 161 melt rock and the microbasalts resemble melted wind-blown dust and regolith debris (Humayun 162 et al., 2013). The dense ICM consists of anhedral micrometer-sized plagioclase embedded in 163 sub-micrometer sized pyroxene, plus fine-grained Fe-(Ti) oxides - magnetite and maghemite 164 (Muttik et al., 2014; Leroux et al., 2016). Disturbances in several isotopic systems (U-Pb in 165 zircon; $\mathrm{K}-\mathrm{Ar} / \mathrm{Ar}-\mathrm{Ar} ; \mathrm{Pb}-\mathrm{Pb}$ in phosphates; bulk-rock $\mathrm{Re} / \mathrm{Os}$ systematics) indicate a probable 166 major reheating event that annealed the breccia at 1.35-1.4 Ga (Humayun et al., 2013; 167 McCubbin et al., 2016; Bellucci et al., 2015; Goderis et al., 2016; Hewins et al., 2017; Cassata et 168 al., 2018; see also Leroux et al., 2016).

169 170 171 172 173 174 175 176 177 178

\section{SULFIDE MINERALOGY OF NWA 7533}

The sulfide mineralogy in NWA 7533 impact breccia was previously studied from the seven polished sections (7533-1 to -7) and one doubly polished transparent thick section (7533LM) available at the Museum National d'Histoire Naturelle (MNHN) (Lorand et al., 2015). NWA 7533 is unique among martian meteorites in being almost devoid of the magmatic sulfide assemblage of igneous origin (i.e. pyrrhotite-pentlandite-chalcopyrite) repeatedly reported in SNC meteorites (e.g. Chevrier et al., 2011; Lorand et al., 2005; 2018a; Baumgartner et al., 2017; Franz et al., 2014; 2019a,b; Dottin et al., 2018; Mari et al., 2019). Ni-bearing pyrrhotite (3 wt\% $\mathrm{Ni})+$ pentlandite; was identified only as three inclusions in plagioclase clasts over the eight polished thick sections investigated. By contrast, accessory pyrite $(0.6-1 \%$ by weight according to an X-Ray distribution map of $\mathrm{S}$ and point counting estimates) is widespread and evenly distributed in all of the impact lithologies (monzonitic and noritic clasts, clast-laden melt rocks (CLMR), melt spherules and microbasalts), in orthopyroxenite clasts from the pristine martian crust, as well as in ICM and the late veins cutting across the meteorite. Hence, pyrite is a latestage mineral that crystallized after the final assembly of the breccia, during the annealing and lithification event presumed to have occurred 1.4 Ga ago (Lorand et al., 2015).

Pyrite crystals show combinations of cubes, truncated cubes and octahedra (average grain size 30-40 $\mu \mathrm{m}$ ). These euhedral crystals were observed mostly inside open cracks, microbasalts and ICM (Fig. 1A). In addition to occurring as euhedral crystals, many pyrites are anhedral 
190 grains, sometimes of very small size (down to $1 \mu \mathrm{m}$ across), especially when disseminated inside 191 ICM (Fig. 1B). Some anhedral pyrite grains replace low-Ca pyroxene clasts. Whether euhedral 192 or anhedral, many pyrite grains are poikiloblastic and enclose relict micron-sized Fe-(Ti) oxides 193 identified as being the same composition and habit as the magnetite-maghemite that is so 194 abundant in NWA 7533 (Fig. 1B). Pyrite-producing reactions thus involved sulfidation, either 195 from magnetite/maghemite, from the low-Ca pyroxene, or from dissolved divalent iron in a fluid. 196 Regardless of their mode of formation, NWA 7533 pyrite grains show nickel-rich areas (up to 1974.5 wt.\%; EMPA and SEM data) representing former Fe-Ni metal particles, as well as highly 198 siderophile element-rich micro-inclusions (Os, Ir, Ru, Pt, Pd, Re, Mo) interpreted as altered 199 impactor debris of the pre-Noachian meteoritic bombardment (Lorand et al., 2015, 2018b). It 200 was inferred from this maximum $\mathrm{Ni}$ content (positively correlated with $\mathrm{Se}$ ) that pyrite started 201 crystallizing at $400-500^{\circ} \mathrm{C}$. Compared to pyrite, hydrothermal pyrrhotite is very scarce, always 202 anhedral, and highly spongy (see Fig 1C). The assemblage pyrite-pyrrhotite-magnetite and 203 maghemite defines Eh-pH conditions of hydrothermal fluids as near neutral $\mathrm{H}_{2} \mathrm{~S}-\mathrm{HS}$-rich $204(6<\mathrm{pH}<10)$ oxidizing fluids (minimum $\log \mathrm{fO}_{2}$ of $>$ FMQ $+2 \log$ units; Lorand et al., 2015) in 205 agreement with the redox conditions deduced from pyroxene clast decomposition into $\mathrm{Mg}$ 206 rich pyroxene, silica, and Fe-oxide (Leroux et al., 2016). Hydrothermal alteration under 207 oxidizing conditions appears to have given rise to fine-grained Fe-rich phases 208 influencing the magnetic properties of the breccia (Gattaceca et al., 2014).

209 Pyrite, a very fragile mineral, shows planar fractures (Fig. 1) resembling planar 210 deformation features (PDF). The shock creating such planar fractures was a very late event, 211 because pyrite was one of the last phases to crystallize in the breccia on Mars (Lorand et al., 212 2015). The fractures were possibly related to the excavation event that liberated the meteorite 213 from the martian subsurface crust, yet its shock intensity could not be determined due to the lack 214 of olivine and quartz (Hewins et al., 2017). These fractures acted as preferential pathways for 215 partial replacement of pyrite by iron oxyhydroxides of terrestrial origin according to their $\mathrm{D} / \mathrm{H}$ 216 values and their distribution defining an alteration gradient throughout the meteorite (Lorand et 217 al., 2015). Electron Microprobe analyses (EMP) of altered and hydrated regions in pyrite show 218 compositions similar to that of goethite, but containing $\sim 4 \% \mathrm{SiO}_{2}$ while electron diffraction data 
219 indicate the presence of hematite, as well. These oxide mixtures will be treated as iron 220 oxyhydroxides in the present paper (see Table S20 in Hewins et al., 2017).

221

222

223

224

225

226

227

228

229

230

231

232

233

234

235

236

237

238

239

240

241

242

243

244

245

246

247

248

249

250

\section{ANALYTICAL METHODS}

The bulk analyses of the meteorite were performed on two powder splits (BB UMD 1 and BB UMD 2) of 0.6 grams each. Both replicates yielded very similar results in terms of S contents and $\mathrm{S}$ isotopic compositions (see below), so we assume that these powder splits were representative of the entire breccia. Bulk sulfur abundances and sulfur isotopic compositions of the bulk sulfur fractions were obtained at the University of Maryland, according to a technique described in detail in Labidi et al. (2012). Briefly, powdered samples were digested in Teflon vessels while continuously flushed with pure $\mathrm{N}_{2}$. Twenty milliliters (ml) of $2.1 \mathrm{M} \mathrm{CrCl}_{2}$ solution and $5 \mathrm{ml}$ of $29 \mathrm{~N} \mathrm{HF}$ (48\%, ultrapure) were used to digest the samples. The $\mathrm{H}_{2} \mathrm{~S}$ released in this process was flushed to a sulfide trap filled with $\mathrm{AgNO}_{3}$ solution $(0.3 \mathrm{M})$ where it reacted to precipitate $\mathrm{Ag}_{2} \mathrm{~S}$. After each extraction and for all samples, weighed $\mathrm{Ag}_{2} \mathrm{~S}$ precipitate is compared to the S content obtained with EMP and used to determine extraction yields. Weighed silver sulfide samples were subsequently wrapped in Al-foil and placed in Ni reaction vessels for fluorination with at least 10 times excess of pure $\mathrm{F}_{2}$ at $250{ }^{\circ} \mathrm{C}$ overnight. The $\mathrm{SF}_{6}$ produced was isolated from impurities using cryogenic and chromatographic techniques. The volume of purified $\mathrm{SF}_{6}$ was then measured with a manometer and transferred to the dual inlet of a ThermoFinnigan MAT 253 isotope ratio gas-source mass spectrometer that was used to measure ion beams at $\mathrm{m} / \mathrm{z}=127+, 128+, 129+$ and $131+$. Once $\delta^{\mathrm{n} S}$ values are determined $(\mathrm{n}=33,34$, 36), $\Delta^{33} S$ and $\Delta^{36} S$ are calculated $\left(\Delta^{33} S=\delta^{33} S-1000\left(\left(\delta^{34} S / 1000+1\right)^{0.515}-1\right)\right.$ and $\Delta^{36} S=\delta^{36} S-$ $1000\left(\left(\delta^{34} \mathrm{~S} / 1000+1\right)^{1.90}-1\right)$. IAEA S1 values are used to evaluate our long-term accuracy and precision on standards, and to anchor our $\delta^{34} \mathrm{~S}$ to the V-CDT scale. Analyses of the S1 standard performed along with the Mars rock analyses yield average $\delta^{34} S, \Delta^{33} S$ and $\Delta^{36} S$ values of $5.28 \pm 0.09 \%$, $+0.083 \pm 0.008 \%$ and $-0.78 \pm 0.26 \%$ o $(n=13$, all 2 s.d. $)$ relative to our reference gas (see details in Labidi et al. 2017). Relative to the same reference gas, our CDT yield $\delta^{34} \mathrm{~S}, \Delta^{33} \mathrm{~S}$ and $\Delta^{36} \mathrm{~S}$ values at $-4.88 \pm 0.15 \%,-0.035 \pm 0.008 \%$ and $-0.08 \pm 0.08 \%$ o ( $\mathrm{n}=6$, all 2 s.d.). The $\mathrm{S}$ isotope shift for $\delta^{34} \mathrm{~S}, \Delta^{33} \mathrm{~S}$ and $\Delta^{36} \mathrm{~S}$ between CDT and $\mathrm{S} 1$ is comparable to what was obtained elsewhere (Ono et al., 2006; Labidi et al., 2012). We use the CDT scale to anchor our $\delta^{34} \mathrm{~S}, \Delta^{33} \mathrm{~S}$ 
251 and $\Delta^{36} \mathrm{~S}$ values. We additionally report our $\delta^{34} \mathrm{~S}$ values on the $\mathrm{V}$-CDT scale to allow 252 comparisons with other datasets that also reported $\delta^{34} \mathrm{~S}$ values relative to V-CDT (e.g., terrestrial 253 mantle-derived rocks, Labidi et al. 2012). We obtained $2 \sigma$ uncertainties of $0.10,0.012$ and $254 \quad 0.25 \%$ for $\delta^{34} \mathrm{~S}, \Delta^{33} \mathrm{~S}$ and $\Delta^{36} \mathrm{~S}$ values, respectively, for all measurements with a $\mathrm{SF}_{6}$ amount $>1$ $255 \mu \mathrm{mol}$.

256

257

258

259

260

261

262

263

264

265

266

267

268

269

270

271

272

273

274

275

276

277

278

279

280

281

The in-situ analyses of S multi-isotopes were done with ion probes on two polished thin sections (7533-4 and 7533-5) over the 8 available. These two polished thin sections show unaltered pyrite crystal cores large enough to be analysed. The dimensions and localisation of the final ion microprobe spots were checked with a scanning electron microscope (Tescan VEGA II LSU Scanning Electron Microscope (SEM) operating in conventional (high-vacuum) mode, and equipped with an SD3 (Bruker) EDS detector (Muséum National d'Histoire Naturelle Paris, France $=\mathrm{MNHN}$ ) operating in the backscattered mode (BSE) (see Lorand et al., 2015 for more details). Major element compositions of pyrite (Fe, Ni, S) were determined with the same standard-less Energy Dispersive procedure as in Lorand et al. (2015) inside the ion beam craters of SIMS analysis; these latter analyses agree quite well with pyrite compositions reported in Lorand et al. $(2015 ; 2018 b)$

Two Cameca IMS 1280 facilities (CRPG, Nancy, France; NordSIMS facility, Stockholm, Sweden) (Table 1) were used. The analytical method for the CRPG Cameca IMS 1280 HR2 is described in detail in Thomassot et al. (2009) and in Muller et al. (2016). Sulfur isotope compositions of sulfides from thick section 7533-5 were measured by simultaneous measurements of ${ }^{32} \mathrm{~S}^{-},{ }^{33} \mathrm{~S}^{-},{ }^{34} \mathrm{~S}^{-}$, and ${ }^{36} \mathrm{~S}^{-}$in multicollection mode with three off-axis Faraday cups (L'2, C and H1) that were intercalibrated before each session of analyses, and one electron multiplier $(\mathrm{H} 2)$ for the most rare isotope $\left({ }^{36} \mathrm{~S}\right)$. The analytical settings were: $5 \mathrm{nA}, \mathrm{Cs}^{+}$- primary beam focused to a spot of about $15 \mu \mathrm{m}$, with secondary intensities from $8.2 \times 10^{8}$ to $10.2 \times 10^{8}$ cps for ${ }^{32} \mathrm{~S}$, depending on the mineralogy. Gains and backgrounds of the Faraday cups were regularly measured during the entire session. Measurements were performed with an automatic centering process and consist of 30 cycles of 4 seconds each after a pre-sputtering time of 300 seconds. The background of the detectors was measured during the pre-sputtering and was then used to correct each analysis. The internal precision achieved under these conditions was better than $0.05 \%$ or for $\delta^{34} \mathrm{~S}$ and $0.03 \%$ for $\delta^{33} \mathrm{~S}$ values $(2 \sigma)$. The external precision, determined from repeated measurements on various reference materials, was $0.40 \%$ o $(2 \sigma)$ for $\delta^{34} S, 0.09 \%$ o $(2 \sigma)$ for 
$282 \Delta^{33} \mathrm{~S}$ values and $0.24 \%$ for $\Delta^{36} \mathrm{~S}$. Several pyrite in-house reference materials (Maine, Philippot et 283 al., 2012, Balmat pyrite, courtesy of M. Whitehouse, and Spain-CR, Muller et al., 2016) were 284 used to determine (i) the instrumental mass fractionation, and (ii) the reference mass 285 discrimination line, from which $\Delta^{33} \mathrm{~S}$ and $\Delta^{36} \mathrm{~S}$ values were calculated. The values of the in-house 286 reference materials can be found in Muller et al. (2017). The bulk isotopic compositions of these 287 materials were measured by conventional gas source mass spectrometer at IPGP following 288 Labidi et al. (2012).

289 Quadruple S-isotopes were measured in-situ on section 7533-4 at a ca. $10 \mu \mathrm{m}$ scale using 290 a CAMECA ims1280 SIMS instrument (NordSIMS facility, Stockholm), closely following 291 analytical protocols outlined by Whitehouse (2013). The sulfur isotopes ${ }^{32} \mathrm{~S},{ }^{33} \mathrm{~S}$ and ${ }^{34} \mathrm{~S}$ were 292 measured on Faraday detectors, while ${ }^{36} \mathrm{~S}$ was measured on an ion counting electron multiplier, 293 corrected for drift using interspersed reference materials (Balmat and Ruttan pyrites), which 294 were also used to correct for instrumental mass bias. Isua pyrite was used to monitor the mass 295 independent values.

296 Sulfur contents of Fe oxyhydroxides and apatite that may be potential S reservoirs (e.g. 297 Parat et al., 2011) were analysed in-situ using a Laser Ablation Inductively Coupled Plasma 298 Mass Spectrometer -LA-ICP-MS) at the «Laboratoire de Planétologie et Géodynamique" in 299 Nantes (France) following the procedure described in detail by Lorand et al (2018b). The 300 samples were ablated and analysed for ${ }^{34} \mathrm{~S}$ using a Bruker 880 quadrupole ICP-MS coupled with 301 a Photon Machine Analyte ${ }^{\mathrm{TM}} \mathrm{G} 2$ equipped with an excimer laser (193 $\mathrm{nm}$ laser wavelength) and 302 a dual volume sample cell that keeps the sample volume small and constant. The laser was 303 operated with a repetition rate of $10 \mathrm{~Hz}$ and a laser output energy of $90 \mathrm{~mJ}$ with a $50 \%$ attenuator 304 and 20x demagnification, resulting in low fluences on the sample $\left(<4 \mathrm{~J} / \mathrm{m}^{2}\right)$. Spot sizes for 305 standards and samples were set to $25-50 \mu \mathrm{m}$ depending on the size of the mineral grains. Six Fe 306 oxyhydroxide grains replacing pyrite were analysed in section 7533-5 with a spot size of $25 \mu \mathrm{m}$, 307 NIST 610 glass as calibration standard and $\mathrm{SiO}_{2}$ content as internal standard, based on the values 308 published by Lorand et al. (2015) and Hewins et al. (2017). Eight apatite crystals from NWA $3097533-5$ were analysed with a laser spot size of $50 \mu \mathrm{m}$, NIST 612 glass as calibration standard 310 and $\mathrm{Ca}$ as internal standard based on the apatite analyses reported by Hewins et al. (2017). 311 Concentrations in both cases were determined using Glitter ${ }^{\mathrm{TM}}$ software (Table 2). 
313

314

315

316

317

318

319

320

321

322

323

324

325

326

327

328

329

330

331

332

333

334

335

336

337

338

339

340

341

342

\section{RESULTS}

The two bulk-rock analyses yield quite reproducible bulk S concentrations (805-920 ppm). These bulk chemistry values are very close to the mean value calculated from LA-ICP-MS raster analyses of Humayun et al. (2013) although the latter method detected huge variations (100 to $1500 \mathrm{ppm}$ ) between each of the breccia components (CLIMR, ICM, microbasalts, melt spherules; see section 2), reflecting small scale variations in modal abundances and weathering degrees of pyrite (Lorand et al., 2015; 2018b). The samples yield an average $\Delta^{33} \mathrm{~S}$ of $0.029 \pm 0.010 \%$ reflecting a small but resolvable non-zero signal in $\Delta^{33} \mathrm{~S}$ at the $2 \sigma$ level. This non-zero $\Delta^{33} \mathrm{~S}$ is coupled with negative $\delta^{34} \mathrm{~S}(-2.54 \pm 0.10 \%$ ). The NWA 7533 meteorite $\mathrm{S}$ isotopic composition is distinct from that of the juvenile martian $\mathrm{S}$ isotopic composition calculated by Franz et al. (2019) from 47 shergottite analyses $\left(\delta^{34} \mathrm{~S}=-0.24 \pm 0.05 \%\right.$, $\Delta^{33} \mathrm{~S}=$ $0.0015 \pm 0.0016 \%, \Delta^{36} \mathrm{~S}=0.039 \pm 0.054 \%$ o).

In addition to bulk isotope measurements, 29 spot analyses were performed on 18 pyrite and 3 pyrrhotite grains of sufficient size $(>20 \mu \mathrm{m})$ that were not significantly altered to Feoxyhydroxides. Ion microprobe measurements yielded more negative $\Delta^{33} \mathrm{~S}$ values $\left(-0.05<\Delta^{33} \mathrm{~S}<\right.$ $0.38 \%$,) compared to the bulk-rock analyses, and a wider range of negative $\delta^{34} \mathrm{~S}$ signatures ($1.5<\delta^{34} \mathrm{~S}<-3.1 \%$; with outliers up to -5.5 and $+0.6 \%$ ) (Fig. 2). The Nancy SIMS analyses show a larger scatter in the $\delta^{34} \mathrm{~S}$ and $\Delta^{33} \mathrm{~S}$ values than the bulk analyses and include two positive values for $\Delta^{33} \mathrm{~S}(0.24-0.35 \%$ corresponding to Site 16-1 and Site F-4 pyrites; Table 1). The ranges of $\Delta^{36} \mathrm{~S}$ are similar: -0.55 to $+0.49 \%$ (NORDSIMS) vs. -0.9 to $+0.49 \%$ (Nancy SIMS), excluding one outlier at -2.2\% (Site B-1 Pyrite). Correlation between $\Delta^{33} \mathrm{~S}$ and $\delta^{34} \mathrm{~S}$ is lacking (Fig. 2). There are no correlations between sulfur isotopic compositions and pyrite Ni contents $(<0.1-3$ wt.\%; Table 1)(Fig. 3), suggesting that the correction procedure of SIMS analyses was not affected by the small deviation of NWA 7533 pyrite compared to pure $\mathrm{FeS}_{2}$. The spread in the $\delta^{34} \mathrm{~S}$ values seems to be due to beam overlap over polymineralic aggregates (pyrite-Fe oxides or Fe oxyhydroxides), matrix silicates or vein-filling terrestrial products (calcite). The analyses having incorporated some calcite seem to shift $\delta^{34} \mathrm{~S}$ toward more positive values (7533-5-19; 7533-5-17; 7533-5-F-2; 7533-5-1a) (Fig. 1). No systematic trend can be seen for those analyses overlapping Fe oxyhydroxides or matrix silicates ( $\delta^{34} \mathrm{~S}$ down to $-5.58 \%$ o for NWA7533-5-G). 
The six pyrite crystals analysed with the NORDSIMS ion microprobe show a very similar range of negative $\Delta^{33} S$ values $\left(-0.05 \% 0<\Delta^{33} S<-0.36 \% 0\right)$ to the 12 Nancy SIMS pyrite analyses, however with no positive values. Both data sets also yield consistent results with regard to the negative $\delta^{34} S$ value of NWA 7533 sulfides $\left(-3.3 \%{ }_{0}<\delta^{34} S<-1.5 \%\right.$ \% $)$. Duplicate analyses generated variable reproducibility that reflected the different degrees of sulfide alteration from one section to another (e.g. site 16a,b; Table 1), and the grain size of the preserved pyrite. Pyrite and the three highly spongy pyrrhotite grains of hydrothermal origin analysed here carry similar isotopic compositions at the 2-sigma level (Table 1; Fig. 2). Due to their lower count rate the NordSIMS analyses of pyrrhotite are less precise compared to the analyses of pyrite, as shown by the two sigma values of the three $\mathrm{S}$ isotope ratios. This lower precision may result from the highly spongy nature of that pyrrhotite, showing pore sizes much smaller $(<1 \mu \mathrm{m})$ than the ion beam diameter $(>10 \mu \mathrm{m})$.

\section{DISCUSSION}

At first sight, the occurrence of Mass Independent Fractionation of sulfur (S-MIFs) supports a martian origin for sulfur in NWA 7533 as deduced from microtextural and compositional characteristics of NWA 7533 pyrite (Lorand et al., 2015). Indeed, S-MIFs are generated by UV-induced photochemical processes in an atmosphere poor in $\mathrm{O}_{2}$ like the martian atmosphere since the earliest times (e.g. Farquhar et al., 2000, 2001; Pavlov and Kasting, 2002). In oxygen isotopes, MIF effects also affect the bulk-rock composition of NWA 7034 (Agee et al., 2013), phosphates (Belluci et al., 2020) and are largest in NWA 7533 zircons (Nemchin et al., 2014). Moreover, the variation in $\Delta^{33} \mathrm{~S}$ with an absence of significant anomalies in $\Delta^{36} \mathrm{~S}$ (Fig. 4) is considered to be diagnostic of S-MIF production on Mars, by different pathways from those that operated on the early Earth and in Earth's stratosphere today (see e.g. Masterson et al., 2011). The calculated mean $\Delta^{36} \mathrm{~S}$ value from both the bulk-rock and SIMS analyses is close to $0 \%$, a characteristic feature of S multi-isotope systematics of martian meteorites compared to Archean terrestrial samples showing mass independent signatures (Franz et al., 2014, 2019a,b)(Fig. 4). The plot in Fig. 4 also rules out alternative fractionation processes, such as, for example, mass-dependent fractionation during Rayleigh distillation with alternative mass laws 
372 (e.g. Young et al., 2002). This latter process should produce a regression line characterized by a 373 slope of $-7 \pm 1$ whereas our data set does not align on any correlation at all. However, it is worth 374 noting that all but three analyses of NWA 7533 sulfides plot within the scattergram of nakhlites 375 in the $\Delta^{36} \mathrm{~S}$ vs. $\Delta^{33} \mathrm{~S}$ plot of Fig. 4. This may be more than a coincidence because NWA 7533 376 sulfides were dated at $1.4 \mathrm{Ga}$, like nakhlites that recorded sulfate contamination at each stage of 377 their petrogenetic history (e.g. Franz et al., 2014; Dottin et al., 2018; Lindsay et al., submitted). 378 This could reflect the $\mathrm{S}$ isotopic composition of surficial sulfur at that time on the martian crust, 379 or a specific S reservoir sampled by both martian breccias and nakhlites.

380 The presence of sulfur isotopic variations that are both mass-independent and

381

382

383

384

385

386

387

388

389

390

391

392

393

394

395

396

397

398

399

400

401 mass-dependent compared to the inferred composition of martian mantle-derived sulfur, argues in favor of a crustal origin of NWA 7533 pyrite consistent with its hydrothermal origin (Lorand et al., 2015). Even taking into account only the bulk-rock data, the small but significant negative $\Delta^{33} \mathrm{~S}$ values overlap with the isotopic $\mathrm{S}$ compositions reported for some shergottites that are now considered to have assimilated crustal sulfur (NWA 11300; NWA 7635; Franz et al., 2019). Before further discussion, it is necessary to address any bias in the database. Hence, the following three points will be addressed 1) how can the slight discrepancy between in-situ analyses and bulk-rock determination of $\Delta^{33} \mathrm{~S}$ be explained, 2) how was anomalous $\mathrm{S}$ transferred to impact breccias, and 3) what was the ultimate process that triggered hydrothermal cycling of $\mathrm{S}$ in these martian regolith breccias.

\section{The balance of the bulk-rock S multi-isotope budget of NWA 7533}

Anomalous $\Delta^{33} \mathrm{~S}$ for pyrite was observed with two different ion microprobes in two different laboratories. This argues for a significant negative $\Delta^{33} \mathrm{~S}$ anomaly as measured by SIMS, which seems to conflict with the near-zero $\Delta^{33} \mathrm{~S}$ value of $-0.029 \pm 0.010 \%$ measured with precise bulk $\mathrm{S}$ isotope measurements. It is not the first time that in-situ analyses and bulk-rock determination of $\mathrm{S}$ isotopes do not match. Franz et al. (2014) documented quite a large discrepancy between SIMS analyses and chemical extractions of MIL 03346 pyrrhotite $\left(\Delta^{33} \mathrm{~S}=\right.$ $0.73 \pm 0.13$ vs. $-0.43 \%$ ) but did not propose a reason for the discrepancy. Dottin et al. (2018) also reported SIMS analyses of nakhlites paired with MIL 00336 yielding lower $\Delta^{33} \mathrm{~S}$ compared to bulk rocks, and argued that the SIMS measurements captured a different population of sulfides 
402 than the bulk analyses. Another possible source of analytical bias is that S-bearing phases other 403 than the two Fe-sulfides, pyrrhotite and pyrite, were overlooked by petrographic studies.

404

405

406

407

408

409

410

411

412

413

414

415

416

417

418

419

420

421

422

423

424

425

426

427

428

429

430

Sulfur in NWA 7533 was identified as residing in both magmatic sulfide assemblages, apatite and Fe-oxyhydroxides (Lorand et al., 2015; this study). As said before, the impact breccia is almost devoid of magmatic sulfides, which is interpreted to result from repeated impact and shock melting. It is well known that shock melts are strongly degassed (Pierazzo and Artemieva, 2012; Righter et al., 2015). Nickel, a strongly chalcophile element was demonstrated to behave as a lithophile element in impact-melt derived noritic and monzonitic clasts that crystallized without evolving sulfide melts (Hewins et al., 2017 and references therein). The paucity of magmatic sulfides in NWA 7533 clearly reflects the repeated heavy bombardment of the martian regolith. Another potential S carrier in igneous rocks is apatite (Parrat et al., 2011) which is a late magmatic mineral in lithic clasts and microbasalts of the breccia (Hewins et al., 2017). NWA 7533 apatite S content determined by LA-ICP-MS is quite homogeneous (200-300 ppm; Table 2). However, apatite is a minor mineral ( $<6$ vol\% in NWA 7034, paired with NWA 7533; Agee et al., 2013) and its contribution to the whole rock S budget is expected to be negligible $(<15$ ppm vs. $865 \mathrm{ppm})$. Its effect on the $\mathrm{S}$ isotopic composition is difficult to predict without a reliable apatite standard for SIMS isotope analyses. However, we can speculate that magmatic sulfides or apatite containing juvenile martian sulfur would drive the $\mathrm{S}$ multi-isotope composition of NWA 7533 toward $0 \%$ in the $\delta^{34} \mathrm{~S}$ vs. $\Delta^{33} \mathrm{~S}$ diagram of Fig. 2. Alternatively, Humayun et al. (2014) suggested that NWA 7533 lithic clasts crystallized from impact melts that incorporated already weathered clay-rich martian soils. In that case, evidence from SNC meteorites and analyses of Gale crater sulfates (Greenwood et al., 2000; Farquhar et al., 2007; Franz et al., 2014, 2017, 2019, Dottin et al., 2018; Mari et al., 2019) predict deviation of $\delta^{34} \mathrm{~S}$ toward strongly positive values in Fig. 2. Clearly, neither magmatic sulfides nor apatite could account for the dilution of the pre-existing non-zero $\Delta^{33} \mathrm{~S}$ at near constant $\delta^{34} S$ between in-situ SIMS analyses and the two bulk-rock data.

Fe oxyhydroxides contain ten times more $\mathrm{S}$ than does apatite $(3000 \pm 1000$ ppm; now measured in-situ with both EMP and LA-ICP-MS, Table 2). However, simple mass balance calculations suggest that $\mathrm{Fe}$ oxyhydroxides are a negligible $\mathrm{S}$ reservoir, too. They would 
431 represent c.a. 40 ppm S (5\% of the bulk-rock S concentration) at best taking into account the 432 highest in-situ measured $\mathrm{S}$ content $(\approx 4,000 \mathrm{ppm})$ and modal abundances of ca. 1 wt.\% (implying 433 a total oxidation of pyrite, which is an over-estimate). Some of the sulfur of Fe oxyhydroxides 434 may come from both oxidized pyrites and terrestrial sources with near-zero $\Delta^{33} \mathrm{~S}$ values, which 435 would explain the shift in the bulk-rock $\Delta^{33} \mathrm{~S}$ values compared to ion microprobe data. From the 436 mass balance calculations, Fe oxyhydroxides would have to have unrealistically positive $\Delta^{33} \mathrm{~S}$ of 437 about +6 to $+9 \%$ to explain the shift of $\Delta^{33} \mathrm{~S}$ from $-0.2 \pm 0.1 \%$ (SIMS data) relative to the 438 bulk value of $-0.03 \pm 0.01 \%$.

439 Sulfates, also major S-bearing phases on Mars (Franz et al., 2017, 2019 and reference 440 therein), have not been detected in martian breccia NWA 7533 despite careful SEM scanning of 441 the 8 polished pieces studied so far (Lorand et al., 2015; Hewins et al., 2017). There are no 442 coupled $\mathrm{Ba}+\mathrm{S}$ spikes that could correspond to barite micro-inclusions in the time-resolved 443 diagram of the LA-ICP-MS analyses of Fe oxyhydroxides (Fig. 5). Barium was systematically 444 detected along with $\mathrm{S}$ (in agreement with EMP and TEM data for $\mathrm{Ca}, \mathrm{S}$ and $\mathrm{Si}$ ). The $\mathrm{Sr}$ and $\mathrm{Ba}$ 445 ion signals are highly correlated and the ${ }^{34} \mathrm{~S}$ signal follows the $\mathrm{Ba}$ and $\mathrm{Sr}$ signals very closely in 446 the first portion of the scan in Fig. 5, while the Ca signal is independent of the Ba-Sr-S signals. 447 The high Sr might indicate that a Sr-Ba sulfate is the only sulfate present and that it is 448 sufficiently widely distributed at a nanometric scale in the Fe-oxyhydroxides not to form discrete 449 spikes. However, the trend of strongly decreasing S/Se ratio in NWA 7533 Fe oxyhydroxides $450 \quad(137<\mathrm{S} / \mathrm{Se}<1,193)$ compared to their pyrite precursors $(3,500<\mathrm{S} / \mathrm{Se}<54,000)$ supports the 451 hypothesis of extensive leaching of sulfates from the breccia during terrestrial weathering (Fig. 452 6). Such a drop in the $\mathrm{S} / \mathrm{Se}$ ratios is consistent with the well documented differences in the 453 behaviour of S and Se in terrestrial weathering (e.g. Lorand et al., 2003 and ref. therein). Under 454 acidic conditions that characterize terrestrial weathering, both $\mathrm{Se}^{4+}$ and $\mathrm{Se}^{6+}$ tend to adsorb onto 455 naturally occurring Fe oxides and oxyhydroxides while $\mathrm{S}$ is leached as $\mathrm{SO}_{4}{ }^{2-}$ (e.g. Ziemkievics et 456 al., 2011). From pyrite modal abundance (up to 1 wt.\%; Lorand et al., 2015), NWA 7533 should 457 show a bulk-rock $\mathrm{S}$ content of $5,400 \mathrm{ppm} \mathrm{S}$ instead of $865 \pm 80 \mathrm{ppm}$ measured in the present 458 study. This suggests a loss of $80 \% \mathrm{~S}$ as dissolved sulfates during terrestrial weathering, which is 459 consistent with previous estimates, either based on pyrite/Fe oxyhydroxide modal ratios (Lorand 460 et al., 2015) or in-situ analyses of pyrite S and Se contents (Lorand et al., 2018b). 
461 The discussion above casts serious doubt on whether another $\mathrm{S}$ reservoir with a 462 significant effect on bulk $\mathrm{S}$ isotopic composition is present in these breccias. Another possible 463 source of discrepancy between the bulk-rock analyses and in-situ measurements is analytical bias 464 generated by one or both of the two techniques. The bulk-rock analysis involved an extraction 465 procedure of S using a Cr(II) solution (c.f. Labidi et al., 2012) which has been shown to be very 466 inefficient for sulfates. (Gröger et al., 2009). However, this analytical bias was likely negligible 467 because as shown above, NWA 7533 meteorite lacks detectable amounts of sulfates. A 468 systematic analytical bias from both the Nancy and Stockholm SIMS can be ruled out because 469 multiple sulfur analyses were processed in both places the same way using the same reference 470 materials and both were mass resolved from ${ }^{32} \mathrm{~S}^{1} \mathrm{H}$. One may speculate that hydride generation 471 could be a bit higher on the sulfide standard mount block (in epoxy) (or if the standard sulfides 472 themselves are hydrated) than on the meteorite section, thus generating $\Delta^{33} \mathrm{~S}$ values biased 473 towards higher values that would in return make the unknowns lower in $\Delta^{33} \mathrm{~S}$. Another effect that 474 could alter the $\Delta^{33} \mathrm{~S}$ values measured by SIMS is the Faraday amplifier background drift. Many 475 of the sulfides analysed in our paper are yielding somewhat lower $70-80 \%$ count rates than the 476 standards so a small drift would have a disproportionate effect in any drift correction, probably at 477 around the 0.1 permil level (around $1000 \mathrm{cps}$ in $10^{7} \mathrm{cps}$ ), and it would lower $\Delta^{33} \mathrm{~S}$ too. However, 478 there is no direct evidence that this putative drift might have operated during the analytical 479 session of NWA 7533 sulfides. Moreover the background was systematically measured during 480 the pre-sputtering time.

481 The question that arises now is whether the SIMS analyses sampled one or several S 482 populations from the same sulfides (pyrite/and or pyrrhotite). This issue can be addressed by 483 looking at the uncertainty data on the average triple $\mathrm{S}$ compositions reported Table 1 as the 484 simple 2x standard deviation on the values, and the weighted average uncertainty on the data, 485 along with its MSWD value. Both the NORDSIMS and Nancy data set yield similar results :

$486 \square$ large spread of data for $\delta^{34}$ S (MSWD of 42 for the NORDSIMS analyses and 132 for the 487 Nancy analyses), beyond what can be explained by analytical uncertainties. This scatter could 488 represent a real Mass Dependent Fractionation (MDF) trend or a subtle analytical issue. Hence, 489 the weighted average uncertainty is obviously not a useful measure of 490 the scatter for $\delta^{34} \mathrm{~S}$ that integrates a component of geological scatter (MDF). 
492

493

494

495

496

497

498

499

500

501

502

503

504

505

506

507

508

509

510

511

512

513

514

515

516

517

518

519

520

521

522

- $\square \Delta^{33} \mathrm{~S}$ values define statistically single low MSWD (1.1 vs. 1.5 for the Nancy and NORDSIMS data set, respectively) populations that are very slightly negative. In fact, combining both data sets gives a weighted average of $-0.165 \pm 0.032$ permil, not overlapping the bulk value. Of course, the fact that $\delta^{34} \mathrm{~S}$ shows variation means that our analyses may have sampled two (or more) reservoirs that are very slightly different in $\Delta^{33} \mathrm{~S}$. Testing that interpretation from a $\Delta^{33} \mathrm{~S}$ vs. $\delta^{34} \mathrm{~S}$ plot would demand many more analyses with much better individual data uncertainties than we have. In that case, the calculation with standard deviations may apply, which would give a mean $\Delta^{33} \mathrm{~S}$ value of $-0.2 \pm 0.18$ (2SD) for the Stockholm data, $-0.12 \pm 0.22$ (2SD) for the Nancy data and a $-0.16 \pm 0.11 \quad$ (2SD) for the combined dataset. Taken individually, both mean $\Delta^{33} \mathrm{~S}$ values overlap the bulk rock data, but when combined, they do not.

- Our $\Delta^{36} \mathrm{~S}$ averages are similar to each other and within error of the bulk. However, the Nancy data display a greater spread (MSWD of 13) perhaps inconsistent with sampling a single population.

To summarize, the fact that SIMS and bulk-rock data do not overlap at $95 \%$ confidence suggests that the two techniques may have sampled different sulfur isotopic compositions from the same Fe-sulfides, assuming that each data set (the UMD bulk-rock data, the NordSIMS data and the Nancy data) are single populations. Thus, the case for multiple S populations could be stronger than the case for analytical bias. Deciphering which parameter really played the major role in our data set is made difficult by the fact that we are comparing data at the 0.1 permil level which is very close to the limitations of the SIMS method. We also cannot exclude that the tiny pyrite crystals that are well below the size of the SIMS beam (1 vs. $10 \mu \mathrm{m}$, respectively) in impact breccia NWA 7533 show less negative $\Delta^{33} \mathrm{~S}$ compared to the larger crystals measured. Clearly, resolving both issues will demand better spatial resolution and analytical precision than those of present-day SIMS techniques .

\section{Hydrothermal cycling of MIF-bearing S in NWA 7533}

As recalled in the introduction, SNC meteorites that have sampled sub-effusive igneous rocks of the martian crust (i.e. nakhlites) have provided multiple evidence of crustal S contamination that took place throughout the cooling history of these rocks, from the magma crystallization stage to late exposure to hydrothermal fluids and evaporitic brines (see also Dottin 
523 et al., 2018; Franz et al., 2019; Bridges et al., 2019 and reference therein). These rocks produce 524 trends of positive $\delta^{34} \mathrm{~S}$ values coupled with negative $\Delta^{33} \mathrm{~S}$ values with water soluble (Ca sulfates) 525 and acid soluble sulfates (jarosite) in Antarctic nakhlites (McCubbin et al., 2009) defining the 526 highest $\delta^{34} \mathrm{~S}$ endmembers (Fig. 7). Likewise ALH 84001 (a proxy of NWA 7533 orthopyroxene 527 crystal clasts with similar ages of formation; Hewins et al., 2017) incorporated crustal sulfate 528 enriched in ${ }^{34} \mathrm{~S}$ along with anomalous ${ }^{33} \mathrm{~S}\left(\delta^{34} \mathrm{~S}=7.20 \pm 0.15 \%, \Delta^{33} \mathrm{~S}=-0.072 \pm 0.008 \%, \Delta^{36} \mathrm{~S}=\right.$ $5290.02 \pm 0.15 \%$; Franz et al., 2014). We note here that the MIF observed in NWA 7533 (this 530 study) and in the nakhlites (Franz et al., 2014; Dottin et al., 2018) are an order of magnitude 531 smaller than the effects observed in terrestrial Archean pyrites (Farquhar et al., 2000). During the 532 photolysis of $\mathrm{SO}_{2}$, the magnitude of the $\mathrm{S}-\mathrm{MIF}$ effect is dependent on the formation of at least 533 two distinct species, an oxidized sulfate (or gaseous $\mathrm{SO}_{3}$ ) and a reduced sulfur polymer $\left(\mathrm{S}_{2}\right.$ or $\left.\mathrm{S}_{8}\right)$ 534 between which the sulfur isotopes are distributed in a mass-independent manner (Pavlov and 535 Kasting, 2002). The presence of oxidation on Mars' surface evidenced by oxychlorine 536 compounds would oxidize the reduced species, so that practically all sulfur ends up as sulfate at 537 the surface. This would prevent the formation of large MIF effects in surficial sulfate, contrary to 538 initial expectations.

539 540 541 542 543 544 545 546 547 548 549 550 551 552

As suggested by NWA 7533 pyrite, negative $\delta^{34} \mathrm{~S}$ values seem to be a characteristic feature of pyrite occurrences in SNC meteorites. Shearer et al. (1996) and Greenwood et al. (2000) documented a wide range of $\delta^{34} \mathrm{~S}(-9.69 \pm 0.22 \%$ to $7.8 \pm 0.7 \%$ o), as well as anomalous $\Delta^{33} \mathrm{~S}$ signals $(-0.74 \pm 0.39 \%$ and $-0.51 \pm 0.38 \%$ o $)$ in two pyrite grains located in "crushed zones" of ALH 84001 and associated with carbonates interpreted to have hydrothermal origin. Negative $\delta^{34} \mathrm{~S}$ values were also published for Lafayette pyrite resulting from partial replacement of pyrrhotite by sulfur-bearing fluid influx into the nakhlite unit (Greenwood et al., 2000; Fig. 7). The same is true for Chassigny pyrite that replaced pyrrhotite $\left(-4.6 \%_{0}<\delta^{34} \mathrm{~S}<-1.5 \%\right.$; Greenwood et al., 2000). According to Shearer et al. (1996) and Greenwood et al. (2000), igneous pyrrhotite in ALH 84001 was largely converted to pyrite by a secondary alteration process, such as an impact-driven hydrothermal system. A low-temperature $\left(200^{\circ} \mathrm{C}\right)$ hydrothermal influx of volatile components $(\mathrm{S}, \mathrm{C}, \mathrm{H})$ was postulated for this reaction in Chassigny, too (Floran et al., 1978; Peslier et al., 2019; Lorand et al., 2018a and references therein). Using results from the Sample Analysis at Mars (SAM) facility aboard the Curiosity rover, Franz et al (2017) found large 
553 variations in $\delta^{34} \mathrm{~S}$ in ten sites of fluvio-lacustrine sediments filling the Gale Crater that exceed

554

555

556

557

558

559

560

561

562

563

564

565

566

567

568

569

570

571

572

573

574

575

576

577

578

579

580

581

those measured for martian meteorites. They identified quite low $\delta^{34} \mathrm{~S}(-47 \pm 14 \%$ ) at both Cumberland (CB) and Oudam (OU) sites where sulfides (pyrrhotite, pyrite) occur and enrichment in ${ }^{34} \mathrm{~S}\left(0<\delta^{34} \mathrm{~S}<28 \pm 7 \%\right.$ (CDT normalized)) in mudstone-hosted sulfates. They concluded that sulfur isotopic equilibrium between sulfides and sulfates could have been reached through warmed groundwater within several thousand years at 100$150^{\circ} \mathrm{C}$ to yield $\delta^{34} \mathrm{~S}$ depleted sulfides.

A similar process known as Thermochemical Sulfate Reduction (TSR) is assumed to have transferred S-MIF-bearing $\mathrm{S}$ into martian impact breccias. Thermochemical Sulfate Reduction is associated with kinetic fractionation that scales with temperature (Kiyosu and Krouse, 1990). Anhydrite-pyrite fractionation coefficients indicate a difference of 15 per mil at $300^{\circ} \mathrm{C}$ (Shanks, 2014 and references therein) with more positive (heavier) compositions in sulfates compared to pyrite. Typical TSR S isotope fractionations are usually less than $20 \%$ (Machel et al., 1995; Seal, 2006). A crude estimate for initial martian sulfate source enriched in ${ }^{34} \mathrm{~S}$ is suggested by $\delta^{34} \mathrm{~S}$ as high as $4.7 \pm 0.2 \%$ in sulfate extracted from Nakhla (Farquhar et al., 2007). Shergottite sulfates show $\delta^{34} \mathrm{~S}$ of $6.68 \pm 0.15 \%$ (Farquhar et al., 2007). Higher values recorded by sulfate of Antarctic nakhlites MIL 03346 and its pairs (up to $12.39 \%$ ) may reflect input of terrestrial sulfates (Franz et al., 2014), but are not unrealistic for martian sulfates as suggested by analyses of sulfate in fluvio-lacustrine sediments of Gale crater (Franz et al., 2017). Hence, taking into account the extreme isotopic composition of martian sulfates, the isotopic fractionation relationship between NWA 7533 pyrite and putative martian sulfates $\left(\delta^{34} \mathrm{~S}_{\text {sulfate - }}\right.$ pyrite) is about $10 \%$. Such $\delta^{34} \mathrm{~S}$ values require TSR temperatures in excess of $250{ }^{\circ} \mathrm{C}$ using the experimentally derived equation of Kiyosu and Krouse (1990) (see also Machel et al. (1995)). To preserve negative $\delta^{34} \mathrm{~S}$ values, this system must have been open with respect to the supply of sulfate (sulfate supply $>$ sulfate consumption), otherwise pyrite would develop positive $\delta^{34} \mathrm{~S}$ values upon completion of closed system fractionation effects (e.g. Magnall et al., 2016). Such an open system is consistent with the widespread distribution of pyrite inside porosity of each lithogical component of martian breccias, including late veinlets. The TSR process may have contributed along with other petrogenetic processes (magma degassing, weathering......) to the 
582 highly oxidized state of NWA 7533 of $\sim$ FMQ $+2 \log$ units (Leroux et al., 2016; Hewins et al., 583 2017), well above typical martian magmatic conditions. Reduction of one mole of $\mathrm{S}^{6+}$ to $\mathrm{S}^{2-}$ 584 consumes eight moles of electrons and has the potential to oxidize eight moles of $\mathrm{Fe}^{2+}$ to $\mathrm{Fe}^{3+}$ 585 (see detailed calculation in Dottin et al., 2018). Our scenario of precursor sulfates is also 586 supported by the S/Se ratio of NWA 7533 pyrite (3,500-54,000; Lorand et al. 2018b; Fig. 5). 587 Selenium chemistry is strongly tied to S chemistry: both elements can substitute as anions into 588 sulfides while forming oxycompounds hosted in sulfates (Howard, 1977; Huston et al., 1995; 589 Lorand et al., 2003; Ziemkievics et al., 2011 and references therein). Although Se concentration 590 data (and hence S/Se ratio) are not available for martian sulfates, one nakhlite (MIL 03346) that 591 bears multiple evidence of martian sulfate contamination shows a bulk-rock S/Se ratio of up to 59213,385 whereas it is only $3566 \pm 798$ for the shergottites that have incorporated juvenile (mantle593 derived) martian sulfur (Wang and Becker, 2017). Owing to its S/Se ratio up to 54,000, there can 594 be little doubt that NWA 7533 pyrite formed from precursor sulfates (Fig. 6).

595 The Eh-pH redox conditions deduced for NWA 7533 from the Fe-S-O system, and the 596 lack of any firmly identified sulfate, imply that sulfate reduction products were recycled by 597 hydrothermal fluids in the martian breccia as reduced to near-neutral $\mathrm{H}_{2} \mathrm{~S} / \mathrm{HS}^{-}$-rich aqueous 598 fluids (Lorand et al., 2015). Reduction of sulfate during the hydrothermal process would 599 generate $\mathrm{H}_{2} \mathrm{~S}$ and potentially $\mathrm{H}_{2} \mathrm{Se}$ that are likely to precipitate as pyrite in the presence of $\mathrm{Fe}^{2+}$ 600 (Auclair et al., 1987). Experimental studies on terrestrial hydrothermal vent systems demonstrate 601 that at 300 and $350{ }^{\circ} \mathrm{C}$ (a temperature range corresponding to that deduced from the Ni content 602 of NWA 7533 pyrite; Lorand et al., 2015, 2018b), pyrite is expected to be depleted in the heavy 603 isotopes of $\mathrm{S}$ relative to $\mathrm{H}_{2} \mathrm{~S}$ at equilibrium (Seal, 2006; Wu et al., 2010; Gregory et al., 2015; 604 Magnall et al., 2016). Lorand et al. (2015, 2018b) suggested that NWA 7533 pyrite precipitated 605 by direct nucleation or sulfidation reactions between $\mathrm{H}_{2} \mathrm{~S} / \mathrm{HS}$-rich aqueous fluids and Fe from 606 different sources (dissolved ions in the fluid, pyroxene clast, matrix oxides (magnetite, 607 maghemite)). Like pyrite, the negative $\Delta^{33} S$ coupled with negative $\delta^{34} S$ values makes the few 608 fine-grained spongy anhedral pyrrhotite grains identified in the interclast matrix (ICM) of NWA 6097533 crystallization products from fluids that reduced crustal sulfates (Fig. 2). However, the 610 highly resorbed and denticulated shape of these pyrrhotite blebs and their spongy textures 611 compared to euhedral pyrite crystals are noteworthy. Such sulfide textures were reported in SNC 612 meteorites that experienced shock-induced sulfur degassing (Lorand et al., 2012, Gattaceca et al., 
613 2013). Lorand et al. (2012) concluded that pyrite in the strongly shocked chassignite NWA 2737 614 was desulfurized into FeS due the high shock pressure (55 GPa) coupled with strong heating 615 conditions (perhaps up to $800{ }^{\circ} \mathrm{C}$ ) published for this meteorite. In NWA 7533, the shock event 616 postdating pyrite crystallization generated only planar deformation features in pyrite. A 617 desulfurization of pyrite into spongy pyrrhotite is thus considered to be very unlikely. For 618 comparison, pyrite was preserved in Chassigny that experienced a shock pressure of much 619 greater intensity (about $35 \mathrm{GPa}$ with a post-shock temperature of about $300{ }^{\circ} \mathrm{C}$; Lorand et al., 620 2018a). The NWA 7533 spongy pyrrhotite must be interpreted as a metastable hydrothermal 621 product of sulfate reduction reactions reflecting local, transient more reducing conditions during 622 percolation by hydrothermal fluids (see Lorand et al., 2015).

\section{Meteorite impact vs. igneous intrusion as source of NWA 7533 hydrothermal pyrite?}

According to a detailed analysis of pyrite textures and its relationships with silicate 626 lithologies of NWA 7533, hydrothermal alteration took place at a very late stage of the history of 627 the meteorite during and after a lithification and annealing event that made the regolith breccia 628 very cohesive. This annealing event responsible for the lithification of the meteorite likely 629 occurred at $\sim 1.4 \mathrm{Ga}$ from the apatite $\mathrm{U}-\mathrm{Pb}$ ages (Bellucci et al., 2015), the zircon lower intercept 630 ages and the K-Ar ages (Humayun et al., 2013; Lindsay et al., 2014; McCubbin et al., 2016; 631 Cassata et al., 2018) and the whole-rock ${ }^{187} \mathrm{Re} /{ }^{187}$ Os model ages (Goderis et al., 2016). Taking 632 into account the Amazonian age of NWA 7533 pyrite, the water responsible for the hydrothermal 633 event on Mars was likely produced by melting of ice from a subsurface permafrost reservoir. 634 Chlorine was likely present too, as indicated by core-rim increase in $\mathrm{Cl} / \mathrm{F}$ ratio of NWA 7533 635 apatite (Belluci et al., 2016); however, Lorand et al. (2018b) suggested that the chlorine content 636 was significantly low when NWA 7533 pyrite precipitated because this sulfide shows very low 637 contents of the base metals $(\mathrm{Cu}, \mathrm{Zn} . .$.$) that are preferentially transported by Cl-rich acidic fluids.$ 638 This hydrothermal cycling process bears similarities to that documented for nakhlites from the 639 Fe-carbonate + Ca-sulfates + halite veins: Changela and Bridges (2011) argued for an impact640 induced heating event which triggered upward percolation of $\mathrm{H}_{2} \mathrm{O}-\mathrm{CO}_{2}$ fluids from buried ice 641 into the nahklite igneous mass, although both upward and downward percolations were also 642 suggested (see Bridges et al., 2019 and reference therein). A downward percolation of sulfate643 bearing aqueous fluid is considered to be more likely for martian impact breccias; however the 
644 source of heat that triggered this percolation, either an impact or a magmatic event is still 645 debated (Lindsay et al., submitted).

646 Meteorite impacts on rocky planetary bodies have the potential to initiate transient 647 hydrothermal systems if: (i) the target contains sufficient volatiles (e.g. liquid water or ice), and 648 (ii) a substantial heat source is generated (e.g. melt sheet, nearby pluton, raised geothermal 649 gradient) (Newsom, 1980; Abramov and Kring, 2004; Naumov, 2005; Osinski et al., 2013; 650 Koeberl, 2014). Sulfides are common hydrothermal products in impact craters on Earth and 651 mineralisation dominated by pyrite is thought to occur during the latest stages of cooling (Parnell 652 et al., 2010; Simpson et al., 2005; 2017). Geochemical modeling of impact-generated 653 hydrothermal systems for Mars also frequently return pyrite among hydrothermal products (e.g. 654 Schwenzer and Kring, 2013). As shown by these authors, pyrite becomes a major mineral along 655 with hematite for water/rock ratios exceeding 1,000. Such conditions are met inside veins, as 656 observed in NWA 7533 where some cracks are filled with pyrite + maghemite (Lorand et al., 657 2015). Cassata et al. (2018) proposed for NWA 7034 (paired with NWA 7533) a rather different 658 interpretation linking the lithification and annealing event with a thermal dome above deeper 659 intrusives because thermal metamorphism recorded by the K-Ar and U-Pb systems yield plateau 660 age differences that were greater than durations (10's of Ma or less) required to cool shock661 heated basement terrains following large (100 to $200 \mathrm{~km})$ impact events that might have 662 occurred at 1,300 Ma. Magmatism is known to have occurred on Mars at 1.4-1.35 Ga from the 663 nakhlite and chassignite meteorites (Nyquist et al., 2001; Cohen et al., 2017 and references 664 therein), while the impact cratering rate of the martian surface was already considerably reduced 665 at that time (e.g., Moser et al., 2019). However, MacArthur et al. (2019) related the maximum $666{ }^{40} \mathrm{Ar}-{ }^{39} \mathrm{Ar}$ age of $1130-1250 \mathrm{Ma}$ in the NWA 8114 meteorite clast (paired with NWA 7533) 667 analysed by them to an impact shock event and the subsequent high-temperature oxidative 668 breakdown of many of the pyroxenes (also documented in NWA 7533 by Leroux et al., 2016). A 669 simple Fourier cooling model suggested that a burial depth of $5 \mathrm{~m}$ was enough to maintain 670 sufficiently high temperatures $\left(>600^{\circ} \mathrm{C}\right)$ for $\sim 30$ days (MacArthur et al., 2019). With this 671 constraint in hand, one may assume that sulfates in martian breccias may have been reduced to 672 sulfides almost in-situ, implying very little transport of aqueous fluids. 673 674

\section{CONCLUSIONS}


675

676

677

678

679

680

681

682

683

684

685

686

687

688

689

690

691

692

693

694

695

696

697

698

699

700

701

702

703

704

705

706

Pyrite is by far the major host of sulfur in the polymict NWA 7533 breccia and paired meteorites. Apatite and Fe oxyhydroxides are negligible $\mathrm{S}$ carriers, as are the tiny magmatic sulfide grains so far identified. Sulfates (barite or gypsum) have not been firmly identified in the breccia. The initial sulfur content of the breccia inferred from the modal abundance of pyrite and its pseudomorphous Fe-oxyhydroxides is estimated to be $\sim 5,400 \mathrm{ppm}$. The two bulk-rock $\mathrm{S}$ analyses obtained here confirm previous estimates of $80 \% \mathrm{~S}$ loss resulting from terrestrial weathering of NWA 7533 pyrite.

The occurrence of S-MIF in the S multi-isotope composition supports a model of NWA 7533 pyrite formation from martian surficial sulfur that experienced photochemical reaction(s). The slight discrepancy between in-situ SIMS analyses $\left(\Delta^{33} S=-0.2 \pm 0.1 \%\right.$; mean of 29 analyses $)$ and the bulk IRMS analyses $\left(\Delta^{33} \mathrm{~S}=-0.029 \pm 0.010 \% 0\right)$ is tentatively interpreted as a likely sampling bias since only grains $>20 \mu \mathrm{m}$ in size were analyzed.

Negative $\delta^{34} S$ values were previously reported for several occurrences of secondary pyrite in SNC meteorites. Such negative values in the hydrothermal setting of NWA 7533 are reflective of authigenic sulfide precipitated from $\mathrm{H}_{2} \mathrm{~S}$ produced via open-system reduction of sulfates. A transient more reducing stage likely produced the spongy pyrrhotite that carries similar S multi-isotope compositions as that of pyrite.

It is concluded that sulfur was recycled by downward percolation of reduced S-bearing aqueous fluid produced by melting of permafrost. However, the driving force that recycled crustal S in NWA 7533 lithologies, underlying magmatic intrusions or impact-induced heating, is presently unclear.

Acknowledgement We are indebted to L. Labenne for the sample. We are grateful for funding from CNES-INSU grant 2014-PNP (J.-P. L.) and the Agence Nationale de la Recherche (ANR) under the contract ANR16CE310012 entitled Mars Prime. The LA-ICP-MS facility at the LPG Nantes was established by funds from the Region Pays de la Loire. Carole La is thanked for her help with the LA-ICP-MS facility at LPG Nantes; MH was supported by NASA Solar System Workings (NNX16AP98G). The National High Magnetic Field Laboratory is supported by the National Science Foundation through NSF/DMR-1644779 and the state of Florida. The revised version was greatly improved thanks to comments from three reviewers and associate 
707 editor Cyrena Goodrich.

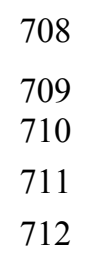

Abramov O. and Kring D. A. 2005. Impact-induced hydrothermal activity on early Mars. Journal of Geophysical Research 110:E12S09. doi:10.1029/ 2005 JE002453.

Agee C. B., Wilson N. V., McCubbin F. M., Ziegler K., Polyak V.J., Sharp Z. D., Asmerom Y., Nunn M. H., Shaheen R., Thiemens M. H., Steele A., Fogel M. L., Bowden R., Glamoclija M., Zhang Z. and Elardo S. M. 2013. Unique meteorite from Early Amazonian Mars: water-rich basaltic breccia Northwest Africa 7034. Science 339:780-785.

Auclair G., Fouquet Y., and Bohn M. 1987. Distribution of selenium in high-temperature hydrothermal sulfide deposits at $13^{\circ}$ North, East Pacific Rise. Canadian Mineralogist 25: 577-588.

Baumgartner R., Fiorentini M., Lorand J.-P., Baratoux D., Zaccarini F., Ferrière L., Prasek M. and Sener K. 2017. The role of sulfides in the fractionation of highly siderophile and chalcophile elements during the formation of martian shergottite meteorites. Geochimica et Cosmochimica Acta 210: 1-24.

Bellucci J. J., Nemchin A. A., Whitehouse M. J., Humayun M., Hewins R. and Zanda B. 2015. $\mathrm{Pb}$-isotopic evidence for an early, enriched crust on Mars. Earth \& Planetary Science Letters 410:34-41.

Bellucci J. J., Whitehouse M. J., Nemchin A.A., Snape J.F., Kenny, G.G., Merle R.E., Bland P.A. \& Benedix G.K. 2020. Tracing martian surface interactions with the triple O isotope compositions of meteoritic phosphates." Earth \& Planetary Science Letters 531:115977.

Bridges J. C. and Grady M. M. 2000. Evaporite mineral assemblages in the nakhlite (martian) meteorites. Earth \& Planetary Science letters 176:267-279.

Bridges J., Hicks J.M. and Treiman A.H. 2019. Carbonates on Mars. “Volatiles in the Martian crust" edited by Filiberto J. and Schwenzer S. P. Amsterdam: Elsevier. pp. 89-118. 
Cassata W. S., Cohen B. E., Mark D. F., Trappitsch R., Crow C. A., Wimpenny J., Lee M. R. and Smith C. L. 2018. Chronology of martian breccia NWA 7034 and the formation of the martian crustal dichotomy. Sci. Adv. 4, eaap 8306, 11 pp.

Changela H. G. and Bridges J. C. 2011. Alteration assemblages in the nakhlites: Variation with depth on Mars. Meteoritics \& Planetary Sciences 45:1847-1867.

Chevrier V., Lorand J.-P. and Sautter V. 2011. Sulfide petrology of four nakhlites (NWA817, NWA998, Nakhla, Governador Valadares). Meteoritics \& Planetary Sciences 46: 769-784.

Dehouck E., Chevrier V., Gaudin A., Mangold N., Mathe P.E. and Rochette P. 2012. Evaluating the role of sulfide-weathering in the formation of sulfates or carbonates on Mars. Geochimica et Cosmochimica Acta 90:47-63.

Dottin J.W., Labidi J., Farquhar J., Piccoli P., Liu M.-C. and McKeegan K.D. 2018. Evidence for oxidation at the base of the nakhlite pile by reduction of sulfate salts at the time of lava emplacement. Geochimica et Cosmochimica Acta 239:186-197.

Farquhar J., Kim S.-T. and Masterson, A. 2007. Implications from sulfur isotopes of the Nakhla meteorite for the origin of sulfate on Mars. Earth Planetary Science Letters 264:1-8.

Farquhar J., Savarino J., Airieau S. and Thiemens M. H. 2001. Observation of wavelengthsensitive mass-independent sulfur isotope effects during $\mathrm{SO}_{2}$ photolysis: Implications for the early atmosphere. Journal of Geophysical Research 106:32829-32839.

Farquhar J., Savarino J., Jackson T. L. and Thiemens M. H. 2000. Evidence of atmospheric sulfur in the martian regolith from sulfur isotopes in meteorites. Nature 404:50-52.

Floran R.J., Prinz M., Hlava P.F., Keil K., Nehru C.E. and Hinthorne J.R., 1978. The Chassigny meteorite: A cumulate dunite with hydrous amphibole-bearing melt inclusions. Chemical Geology 42, 1213-1222.

Foley C.N., Economou T., and Clayton R.N. 2003. Final chemical results from the Mars Pathfinder Alpha Proton X-ray Spectrometer. Journal of Geophysical Research 108, 8096, DOI: $10.1029 / 2002 J E 002019$.

Franz H.H, Kim S.T., Farquhar J., Day J.M.D., Economos R.C., McKeegan K., Schmitt A.K., Irving A.J., Hoek J. and Dottin J. III 2014. Isotopic links between atmospheric chemistry and the deep sulfur cycle on Mars. Nature 508:365-368.

Franz H. B., McAdam A., Ming D. W., Freissinet C., Mahaffy P. R., Eldridge D. L., Fischer W. F., Grotzinger J. P., House C. H., Hurowitz J. A., McLennan S. M., 
767

768

769

770

771

772

773

774

775

776

777

778

779

780

781

782

783

784

785

786

787

788

789

790

791

792

793

794

795

Schwenzer S. P., Vaniman D. T., Archer P. D. Jr, Atreya S. K., Conrad P. G., Dottin J. W. III, Eigenbrode J. L., Farley K. A., Glavin D. P., Johnson S. S., Knudson C. A., Morris R.V., Navarro-Gonzalez R., Pavlov A.A., Plummer R., Rampe E. B., Stern J. C., Steele A., Summons R. E., and Sutter B. 2017. Large sulfur isotope fractionations in Martian sediments at Gale crater. Nature Geoscience 10:658-662.

Franz H. B., King P. L. and Gaillard F. 2019. Sulfur on Mars from the atmosphere to the core. In "Volatiles in the Martian crust" edited by Filiberto J. and Schwenzer S. P. Amsterdam: Elsevier. pp. 119-183.

Gaillard F., Michalski J., Berger G., McLennan S.M. and Scaillet B. 2013. Geochemical reservoirs and timing of sulfur cycling on Mars. Space Science Review 174, 251-300

Gattacceca, J., Hewins, R.J., Lorand, J.-P., Rochette, P., Lagroix, F., Cournède, C., Uehara, M., Pont, S., Sautter, V., Scorzelli, R.B., Hombourger, C., Munayco, P., Zanda, B., Chennaoui, H., 2013. Opaque minerals, magnetic properties and paleomagnetism of the Tissint Martian meteorite. Meteoritics \& Planetary Sciences 48, 10, 1919-1936.

Gattacceca J., Rochette P., Scorzelli R.B., Munayco P., Agee C., Quesnel Y., Cournède C. and J. Geissman J. 2014. Martian meteorites and Martian magnetic anomalies: A new perspective from NWA 7034, Geophysical Research Letters 41, 4859-4864, doi:10.1002/2014GL060464.

Goderis S., Brandon A. D., Mayer B. and Humayun M. 2016. Ancient impactor components preserved and reworked in martian regolith breccia Northwest Africa 7034. Geochimica et Cosmochimica Acta 191, 203-215.

Gooding J.L., Wentworth S.J. and Zolensky M. 1991. Aqueous alteration of the Nakhla meteorite. Meteoritics 326: 135-143.

Greenwood J. P., Mojzsis S. J. and Coath C. D 2000. Sulfur isotopic compositions of individual sulfides in martian meteorites ALH 84001 and Nakhla: Implications for crust-regolith exchange on Mars. Earth \& Planetary Science Letters 184:23-35.

Greenwood J. P., Riciputi L. R., McSween H. Y. Jr. and Taylor L. A. 2000. Modified sulfur isotopic compositions of sulfides in the nakhlites and Chassigny. Geochimica et Cosmochimica Acta 64, 1121-1131. 
796 Gregory D.D., Large R. R., Halpin J.A., Steadman J.A., Hickman H.E., Ireland, T.E. and Holden 797 P. 2015. A degree of sulfate reduction in an open system to produce negative $\delta^{34} \mathrm{~S}$. 798 799 800 801 802 803 Geochimica et Cosmochimica Acta 150:223-250.

Griffin W.L., Powell W.J., Pearson N.J. and O’Reilly S.Y. 2008. GLITTER: Data reduction software for laser ablation ICP-MS: Mineral Association of Canada Short Course Series 40, pp. 308-311.

Gröger, J., Franke, J., Hamer, K. and Schulz, H.D., 2009. Quantitative recovery of elemental sulfur and improved selectivity in a chromium-reducible sulfur distillation. Geostandards and Geoanalytical Research 33(1), pp.17-27.

Grotzinger J.P., Sumner D. Y., Kah L., Stack C. K., Gupta S., Edgar L., Rubin D., Lewis K., Schieber J., Mangold N., Milliken R., Conrad P.G.,DesMarais D., Farmer J., Siebach K., Calef K., Hurowitz J., McLennan S. M., Ming D., Vaniman D., Crisp J., Vasavada A., Edgett K.S., Malin M., Blake D., Gellert R., Mahaffy P., Wiens R. C., Maurice S., Grant J. A., Wilson S., Anderson R. C., Beegle L., Arvidson R., Hallet B., Sletten R. S., Rice M., Bell III J., Griffes J., Ehlmann B., Anderson R. B., Bristow T. F. , Dietrich W. E., Dromart G., Eigenbrode J., Fraeman A., Hardgrove C., Herkenhoff K., Jandura L., Kocurek G., Lee S., Leshin L. A., Leveille R., Limonadi D., Maki J., McCloskey S., Meyer M., Minitti M., Newsom H., Oehler D., Okon A., Palucis M., Parker T., Rowland S., Schmidt M., Squyres S., Steele A., Stolper E., Summons R., Treiman A., Williams R., Ayingst ., MSL Science Team 2014. A Habitable Fluvio-Lacustrine Environment at Yellowknife Bay, Gale Crater, Mars. Science, 343 1242777-1-14.

Hewins R. H., Zanda B., Humayun M., Nemchin A., Lorand J.-P., Pont S., Deldicque D., Bellucci J. J., Beck P., Leroux H., Marinova M., Remusat L., Göpel C., Lewin E., Grange M., Kennedy A. and Whitehouse M. (2017) Regolith breccia Northwest Africa 7533: mineralogy and petrology with impli- cations for early Mars. Meteoritics \& Planetary Sciences 52: 89-124. 
823 Howard J. H. 1977. Geochemistry of Se: formation of ferroselite and Se behavior in the vicinity 824 825 of oxidizing sulfide and uranium deposits. Geochimica et Cosmochimica Acta 41:16651678.

826

827

828

Humayun M., Nemchin A., Zanda B., Hewins R.H., Grange M., Kennedy M., Lorand J.-P., Göpel C., Pont S., Fieni C. and Deldicque D. 2013. Origin and age of the earliest martian crust from meteorite NWA 7533. Nature 503:513-516.

Humayun M., Hewins R. H., Lorand J.-P., and Zanda B. 2014. Weathering and impact melting determined the mineralogy of the early Martian crust preserved in Northwest Africa 7533 (abstract \#1880). 45th Lunar and Planetary Science Conference. CD-ROM.

Huston D. L., Sie S. H., Suter G. F., Cooke D. R. and Both R. A. 1995. Trace elements in sulfide minerals from eastern Australian volcanic-hosted massive sulfide deposits; Part I, Protonmicroprobe analyses of pyrite, chalcopyrite, and sphalerite, and Part II, selenium levels in pyrite; comparison with $\delta^{34} \mathrm{~S}$ values and implications for the source of sulfur in volcanogenic hydrothermal systems. Economic Geology 90:1167-1196.

Kerber L., Forget F. and Wordsworth R. 2015. Sulfur in the early Martian atmosphere revisited: Experiments with a 3-D Global Climate Model. Icarus 261:133-148.

King P.L. and McLennan S.M. 2010. Sulfur on Mars. Elements 6:107-112.

Kiyosu Y. and Krouse R. H. 1990. The role of organic and acid in the in the sulfur abiogenic isotope reduction effect. Geochemistry Journal 24:21-27.

Koeberl C. 2014. The geochemistry and cosmochemistry of impacts. In: Planets, Asteroids, Comets and The Solar System. In: Treatise on Geochemistry, vol.2, 2nd edition. Elsevier, pp.73-118.

Labidi J., Cartigny P., Birck J. L., Assayag N. and Bourrand J. J. 2012. Determination of multiple sulfur isotopes in glasses: a reappraisal of the MORB $\delta^{34}$ S. Chemical Geology 334: 189-198.

Labidi J., Farquhar J., Alexander C.M.O.D., Eldridge D.L., Oduro H. 2017. Mass independent sulfur isotope signatures in CMs: Implications for sulfur chemistry in the early solar system, Geochimica et Cosmochimica Acta 196:326-350. 
852 Leroux H., Jacob D., Marinova M., Hewins R. H., Zanda B., Pont S., Lorand J.-P. and Humayun 853 M. 2016. Exsolution and shock microstructures of igneous pyroxene clasts in the NWA 854 855 856 857 858 859 860 861 862 863 864 865 866 867 868 869 870 871 872 7533 Martian meteorite. Meteoritics \& Planetary Sciences 51:932-945.

Lindsay F. N., Turri, B. D., Göpel C., Herzog G. F., Zanda B., Hewins R., Park J., Delaney J. S. and Swisher C. C. 2014. ${ }^{40} \mathrm{Ar} /{ }^{39} \mathrm{Ar}$ Ages of Martian Meteorite NWA 7533. Meteoritics \& Planetary Sciences 47, Abstract \#5383.

Lindsay F. N., Delaney J. S., Göpel C., Herzog G. F., Hewins R. H., Humayun M., Nagao K., Nyquist L. E., Park J., Setera J. B., Shih C.-Y., Swisher C. C., III, Zanda B. and Turrin B. D. (2020) ${ }^{40} \mathrm{Ar} /{ }^{39} \mathrm{Ar}$ ages of Northwest Africa 7034 and Northwest Africa 7533. Meteoritics \& Planetary Sciences (submitted; MaPS 3348).

Lorand J.-P., Alard O., Luguet A. and Keays R. R. 2003. S/Se systematics of the subcontinental lithospheric mantle beneath the Massif Central. Geochimica et Cosmochimica Acta 67:4137-4153.

Lorand, J.-P., Barat, J.-A., Chevrier, V., Sautter, V. and Pont, S., 2012. Metal-saturated sulfide assemblages in chassignite NWA 2737; evidence for impact-related sulfur devolatilisation. Meteoritics \& Planetary Sciences 47:1830-1841.

Lorand J.-P., Hewins R. H., Pont S., Zanda B., Humayun M. Nemchin A. and others 2015. Nickeliferous pyrite tracks pervasive hydrothermal alteration in martian regolith breccia : a study in NWA 7533. Meteoritics \& Planetary Sciences 50:2099-2120.

Lorand J.-P., Pont S., Chevrier V., Luguet A., Zanda B.and Hewins R. H. 2018(a). Petrogenesis of martian sulfides in the Chassigny meteorite. American Mineralogist, special issue "Planetary Sulfides"103:872-885.

Lorand J.-P., Hewins R. H., Humayun M., Zanda B., Remusat L., La C. and Pont S. 2018(b). Chalcophile-siderophile element systematics of hydrothermal pyrite from martian regolith breccia NWA 7533. Geochimica et Cosmochimica Acta 241:134-149.

MacArthur J. C. Bridges L. J. Hicks Burgess R. Joy, K. H. Branney, M. J. Hansford G. M., Baker S. H., Schwenzer S. P., Gurman S. J., Stephen N. R., Steer E. D., Pierc J. D. and Ireland T. R. 2019. Mineralogical constraints on the thermal history of martian regolith breccia Northwest Africa 8114. Geochimica et Cosmochimica Acta 246:267-298.

Machel H. G., Krouse H. R. and Sassen R. 1995. Products and distinguishing criteria of bacterial and thermochemical sulfate reduction. Applied Geochemistry 10:373-389. 
883 Magnall J.M., Gleeson S.A., Stern R.A., Newton R.J., Poulton S.W. and Paradis S. 2016. Open 884 system sulfate reduction in a diagenetic environment - Isotopic analysis of barite $\left(\delta^{34} S\right.$ and $\left.885 \quad \delta^{18} \mathrm{O}\right)$ and pyrite $\left(\delta^{34} \mathrm{~S}\right)$ from the Tom and Jason Late Devonian $\mathrm{Zn}-\mathrm{Pb}-\mathrm{Ba}$ deposits, Selwyn 886 887 888 889 890 891 892 893 894 895 896 897 898 899 900 901 902 903 904 905 906 907 908 909 910 Basin, Canada. Geochimica et Cosmochimica Acta 180:146-163.

Mari N., Riches A.J.V., Hallis L.J., Marrocchi Y.,Villeneuve J., Gleissner P., Becker H. and Lee, M., 2019. Syneruptive incorporation of martian surface sulphur in the nakhlite lava flows revealed by $\mathrm{S}$ and Os isotopes and highly siderophile elements : implication for mantle sources in Mars. Geochimica et Cosmochimica Acta 266:416-43.

Masterson A.L., Farquhar J. and Wing B. A. 2011. Sulfur mass-independent fractionation patterns in the broadband UV photolysis of sulfur dioxide: Pressure and third body effects . Earth \& Planetary Science letters 306:253-260.

McCubbin F. M., Tosca N. J., Smirnov A., Nekvasil H., Steele A., Fries M. and Lindsley D. H. 2009. Hydrothermal jarosite and hematite in a pyroxene-hosted melt inclusion in martian meteorite Miller Range (MIL) 03346: Implications for magmatic-hydrothermal fluids on Mars. Geochimica et Cosmochimica Acta 73:4907-4917.

McCubbin F. M., Boyce J. W., Nova'k-Szabo' T., Santos A. R., Tartese R., Muttik N., Domokos G., Vazquez J., Keller L. P., Moser D. E., Jerolmack D. J., Shearer C. K., Steele A., Elardo S. M., Rahman Z., Anand, M., Delhaye T. and Agee C. B. 2016. Geologic history of Martian regolith breccia Northwest Africa 7034: evidence for hydrothermal activity and lithologic diversity in the Martian crust. Journal of Geophysical Research 121: 2120-2149.

McLennan S.M., Bell J.F., Calvin M., Christensen P.R., Clark B.C., De Souza P.A., Farmer J., Farrand W.H., Fike D.A., Gellert R., Ghosh A., Glotch T.D., Grotzinger J.P., Hahn B., Herkenhoff K.E., Huorwitz J.A., Johnson J.R., Yen A., 2005. Provenance and diagenesis of the evaporite-bearing Burns formation, Meridiani Planum, Mars. Earth \& Planetary Science Letters 240, 95-121.

Moser D. E., Arcuri G. A, Reinhard D. A., White L. F., Darling J. R., Barker I. R., Larson D. J., Irving A. J., McCubbin F. M., Tait K. T., Roszjar J., Wittmann A. and Davis C. 2019. Decline of giant impacts on Mars by 4.48 billion years ago and an opportunity for early habitability. Nature Geoscience 12:522-527.

913 in Archean sulfates and their implications for the chemistry and dynamics of the early 
atmosphere. Proceedings of the National Academy of Sciences 113:7432-7437.

Muller, E., Philippot, P., Rollion-Bard, C., Cartigny, P., Assayag, N., Marin-Carbonne, J., and Sarma, D. S. 2017. Primary sulfur isotope signatures preserved in high-grade Archean barite deposits of the Sargur Group, Dharwar Craton, India. Precambrian Research 295:38-47.

Nachon M., Clegg S. M., Mangold N., Schroder S., Kah L. C., Dromart G., Ollila A., Johnson J. R., Oehler D. Z., Bridges J. C., Le Mouelic S., Forni O., Wiens R. C., Anderson R. B., Blaney D. L., Bell J. F. I., Clark B., Cousin A., Dyar M. D., Ehlmann B., Fabre C., Gasnault O., Grotzinger J., Lasue J., Lewin E., Leveille R., McLennan S., Maurice S., Meslin P. Y., Rapin W., Rice M., Squyres S. W., Stack K., Sumner D. Y., Vaniman D., and Wellington D. 2014. Calcium sulfate veins characterized by ChemCam/Curiosity at Gale crater, Mars. Journal of Geophysical Research Planets 119:1991-2016.

Naumov M. 2005. Principal features of impact-generated hydrothermal circulation systems: mineralogical and geochemical evidence. Geofluids 5:165-180.

Newsom H. E. 1980. Hydrothermal alteration of impact melt sheets with implications for Mars. Icarus 44:207-216.

Nyquist L.E., Bogard D.D., Shii C.Y., Greshake A., Stöffler D., and Eugster O. 2001. Ages and geological histories of Martian meteorites. Space Science Reviews 96:105-164.

Ohno S., Wing B., Rumble D. and Farquhar J. 2006. High precision analysis of all four stable isotopes of sulfur $\left({ }^{32} \mathrm{~S},{ }^{33} \mathrm{~S},{ }^{34} \mathrm{~S}\right.$ and $\left.{ }^{36} \mathrm{~S}\right)$ at nanomole levels using a laser fluorination isotope-ratio-monitoring gas chromatography-mass spectrometry. Chemical Geology 225:30-39.

Osinski G.R., Tornabene L.T., Banerjee N.R., Cockell C.S., Flemming R., Izawa M.R., McCutcheon J., Parnell J., Preston L.J., Pickersgill A.E., Pontefract A., Sapers H. and Southam G., 2013. Impact-generated hydrothermal systems on Earth and Mars. Icarus 347363.

Parat F., Holtz F. and Streck M. 2011. Sulfur-bearing magmatic accessory minerals. Review Mineralogy and Geochemistry 73:285-314. 
943 Parnell J., Taylor W.C., Thackrey S., Osinski G.R. and Lee P. 2010. Permeability data for impact 944 breccias imply focused hydrothermal fluid flow. Journal of Geochemical Exploration 106: 945 946 947 948 949 950 951 952 953 954 955 956 957 958 959 171-175.

Pavlov A.A. and Kasting J.F. 2002. Mass-independent fractionation of sulfur isotopes in Archean sediments: Strong evidence for an anoxic Archean atmosphere. Astrobiology 2:2741.

Peslier A. H., Hervig R., Yang S., Humayun M., Barnes J.J., Irving A. J. and Brandon A. D. 2019. Determination of the water content and $\mathrm{D} / \mathrm{H}$ ratio of the martian mantle by unravelling degassing and crystallization effects in nakhlites. Geochimica et Cosmochimica Acta 266: 382-415.

Philippot P., Van Zuilen M. and Rollion-Bard C 2012. Variations in atmospheric sulfur chemistry on early Earth linked to volcanic activity. Nature Geoscience 5:668-674.

Pierazzo E. and Artemieva, N. 2012. Local and Global Environmental Effects of Impacts on Earth. Elements 8:55-60.

Righter K., Pando K. and Danielson L. R. 2009. Experimental evidence for sulfur-rich martian magmas: Implications for volcanism and surficial sulfur sources. Earth \& Planetary Science Letters 288: 235-243.

Righter K., Abell P., Agresti D., Berger E.L., Burton A.S., Delaney J. S., Fries M.D., Gibson E.K., Haba M.K., Harrington A., Herzog G.F., Keller L.P., Locke D., Lindsay F.N., McCoy T.J., Morris R.V., Nagao K., Nakamura-Messenger K., Niles P.B., Nyquist L.E., Park J., Peng Z.X.F., Shii C.Y., Simon J.I., Swisher C.C., Tappa M.J., Turrin B.D. and Zeigler R.A 2015. Mineralogy, petrology, chronology, and exposure history of the Chelyabinsk meteorite and parent body. Meteoritics $\mathcal{E}$ Planetary Science 50:1790-1819.

Schwenzer S.P. and Kring, D.A. 2013. Alteration minerals in impact-generated hydrous alteration systems- Exploring host rock variability. Icarus 226: 487-496.

Seal R. 2006. Sulfur isotope geochemistry of sulfide minerals. Review in Mineralogy and Geochemistry 61:633-677. 
971 Shanks W.C., III. 2014. Stable Isotope Geochemistry of Mineral Deposits. Treatise of 972 Geochemistry $2^{\text {nd }}$ edition, Chap. 13.3, pp. 59-85 Elsevier (Carlson and Turekian, eds.)

973

974

975

976

977

978

979

980

981

982

983

984

985

986

987

988

989

990

991

992

993

994

995

996

997

998

999

1000

1001
http://dx.doi.org/10.1016/B978-0-08-095975-7.01103-7.

Shearer C. K., Layne G. D., Papike J. J. and Spilde M. N. 1996. Sulfur isotopic systematics in alteration assemblages in martian meteorite Allan Hills 84001. Geochimica et Cosmochimica Acta 60:2921-2926.

Simpson S.L., Boyce A.J. , Lambert P., Lindgren P. and Lee M.R. 2017. Evidence for an impactinduced biosphere from the $\delta^{34} \mathrm{~S}$ signature of sulfides in the Rochechouart impact structure, France. Earth \& Planetary Science Letters 460:192-200.

Simpson S.L., Osinski G.R., Lee P., Parnell J., Spray J.G. and Baron M. 2005. A case study of impact-induced hydrothermal activity: the Haughton impact structure, Devon Island, Canadian High Arctic. Meteoritics \& Planetary Sciences 40:1859-1877.

Squyres S.W., Arvidson R .E., Bell J.F., Calef F., Clark B.C., Cohen B.A., Crumpler L.A., de Souza P.A., Farrand W.H., Gellert R., Grant J., Herkenhoff K.E., Hurowitz J.A., Johnson J.R., Jolliff $\quad$ B.L., Knoll $\quad$ A.H., Li $\quad$ R., McLennan $\quad$ S.M., Ming $\quad$ D.W., Mittlefehldt D.W., Parker T.J., Paulsen G., Rice M.S., Ruff S.W., Schröder C., Yen A.S., Zacny K. 2012. Ancient impact and aqueous processes at Endeavour Crater, Mars. Science 336:570576.

Syverson D.D., Ono S., Shanks W.C. and Seyfried W.C. Jr. 2015. Multiple sulfur isotope fractionation and mass transfer processes during pyrite precipitation and recrystallization: An experimental study at 300 and $350^{\circ} \mathrm{C}$. Geochimica et Cosmochimica Acta 165:418-434.

Thomassot E., Cartigny P., Harris J., Lorand J.-P., Rollion-Bard C. and Chaussidon M. 2009 Metasomatic diamond growth: A multi-isotope study $\left({ }^{13} \mathrm{C},{ }^{15} \mathrm{~N},{ }^{33} \mathrm{~S},{ }^{34} \mathrm{~S}\right)$ of sulfide inclusions and their host diamonds from Jwaneng (Botswana). Earth \& Planetary Science Letters 282: 79-90.

Tian F., Mark W., Claire B., Jacob D., Haqq M., Smith M., Crisp D.C., Catling D., Zahnle K., and Kasting J.F., 2010. Photochemical and climate consequences of sulfur outgassing on early Mars. Earth \& Planetary Science Letters 295:412-418.

Wentworth S.J. and Gooding J.L. 1994. Carbonates and sulfates in the Chassigny meteorite: Further evidence for aqueous chemistry on the SNC parent planet. Meteoritics \& Planetary Sciences 29:860-863. 


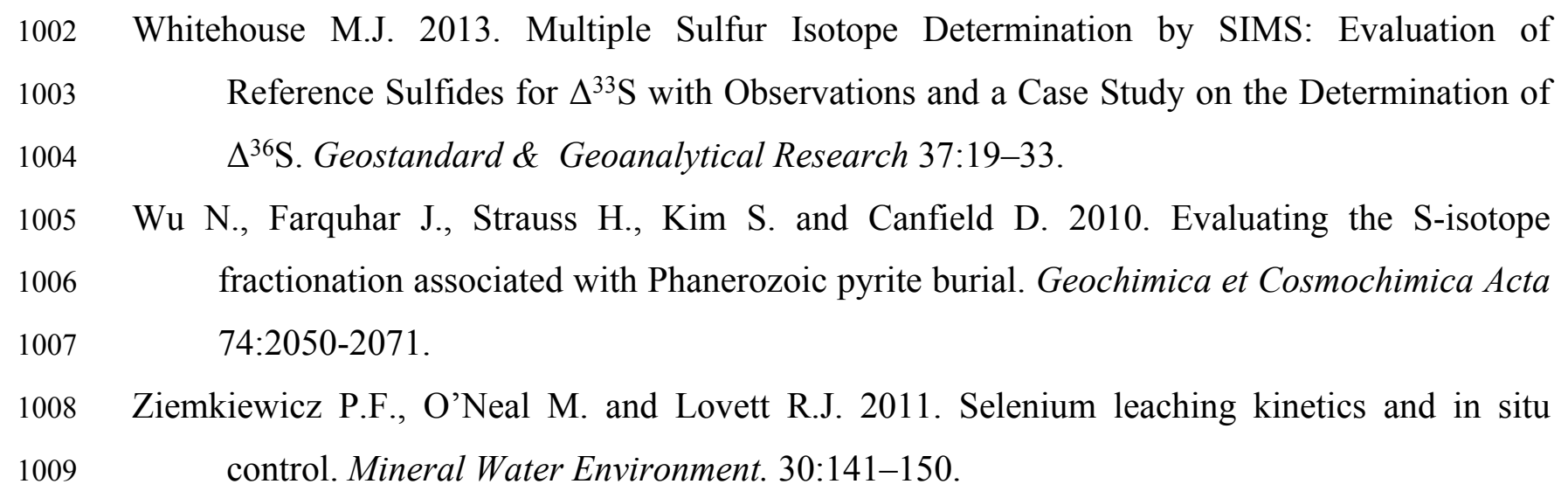




\section{$1013 \quad$ Figure caption}

1014

1015

1016

1017

1018

1019

1020

1021

1022

1023

1024

1025

1026

1027

1028

1029

1030

1031

1032

1033

1034

1035

1036

1037

1038

1039

1040

1041
Figure 1 : Backscattered electron (BSE) images of NWA 7533 Fe sulfides. (A) euhedral pyrite (1) affected by late fracturing that also guided terrestrial weathering (2) dark gray Fe oxyhydroxides); (B) poikilitic pyrite surrounded by a fine-grained dust of ICM minerals; solid inclusions are skeletal Fe oxides (maghemite-magnetite; 3 ) and perfectly euhedral apatite (4); (C) interstitial porous pyrrhotite (5) within interclast matrix (ICM). Note silicate clast inclusions (I) in the pyrrhotite.

Figure $2: \delta^{34} \mathrm{~S}$ vs $\Delta^{33} \mathrm{~S}$ diagram for NWA 7533 sulfides and bulk-rock. $\Delta^{33} \mathrm{~S}=\delta^{33} \mathrm{~S}-1000^{*}$ $\left[\left(\delta^{34} \mathrm{~S} / 1000+1\right) 0.515-1\right]$. Compositional field of shergottites and weighted mean used as revised estimate for the juvenile Martian sulfur composition after Franz et al. (2019), excluding the samples that were described as contaminated by crustal materials. Note the overall negative $\delta^{34} \mathrm{~S}$ values of NWA 7533 sulfides for slightly negative $\Delta^{33} \mathrm{~S}$ values compared to shergottites. Typical error bars on shergottite data display $2 \sigma$ uncertainties.

Figure $3: \delta^{34} \mathrm{~S}$ vs. Ni and $\Delta^{33} \mathrm{~S}$ vs. Ni diagrams for NWA 7533 pyrite (NWA7533-5) (SEM analyses for $\mathrm{Ni}$ ).

Figure $4: \Delta^{33} \mathrm{~S}$ vs. $\Delta^{36} \mathrm{~S}$ diagrams for NWA 7533 sulfides. $\Delta^{36} \mathrm{~S}=\delta^{36} \mathrm{~S}-1000^{*}\left[\left(\delta^{34} \mathrm{~S} / 1000+1\right) 1.9\right.$ 1]. Data for SNC meteorites from Franz et al., (2014, 2019).

Figure 5. Time-resolved LA-ICPMS spectra collected along the laser traverse through a Fe oxyhydroxide pseudomorph replacing pyrite.

Figure 6 : Se vs. S plots for NWA 7533. Color symbols correspond to the rastered LA-ICPMS analyses of the different lithological components of NWA 7533 (Humayun et al., 2013). NWA pyrite and Fe oxyhydroxide compositions from Lorand et al (2018b). The blue arrow depicts the preferential leaching of $\mathrm{S}$ with respect to Se resulting from terrestrial weathering. Putative composition of martian sulfates after Wang and Becker (2017). 


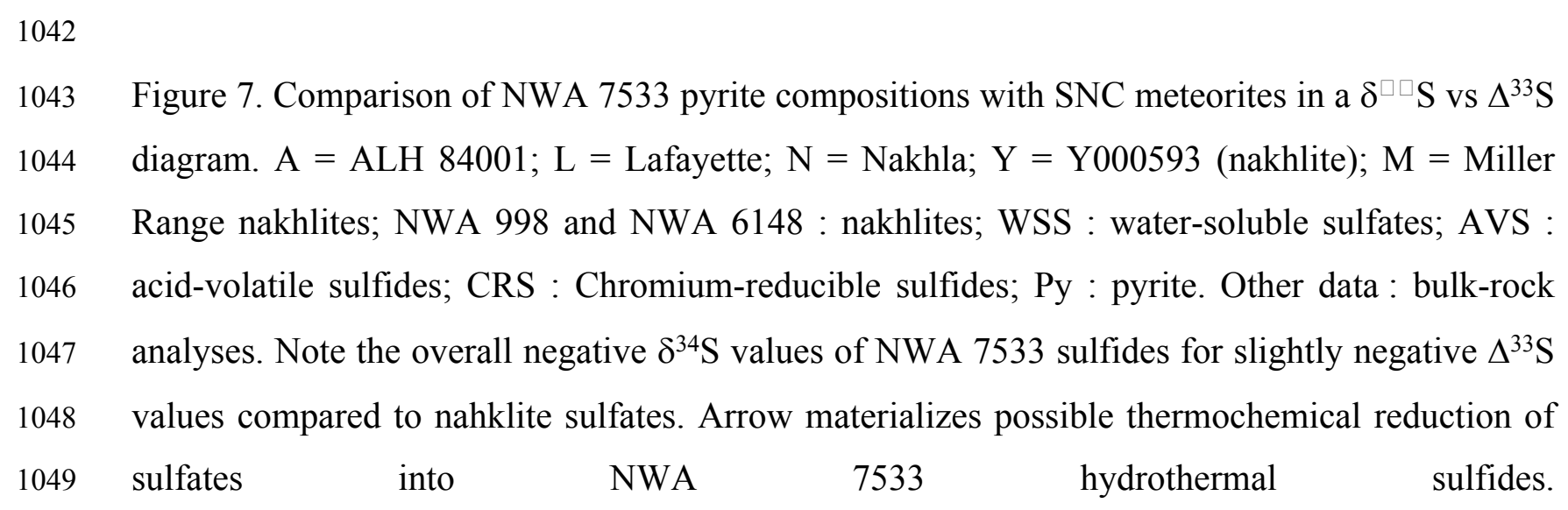



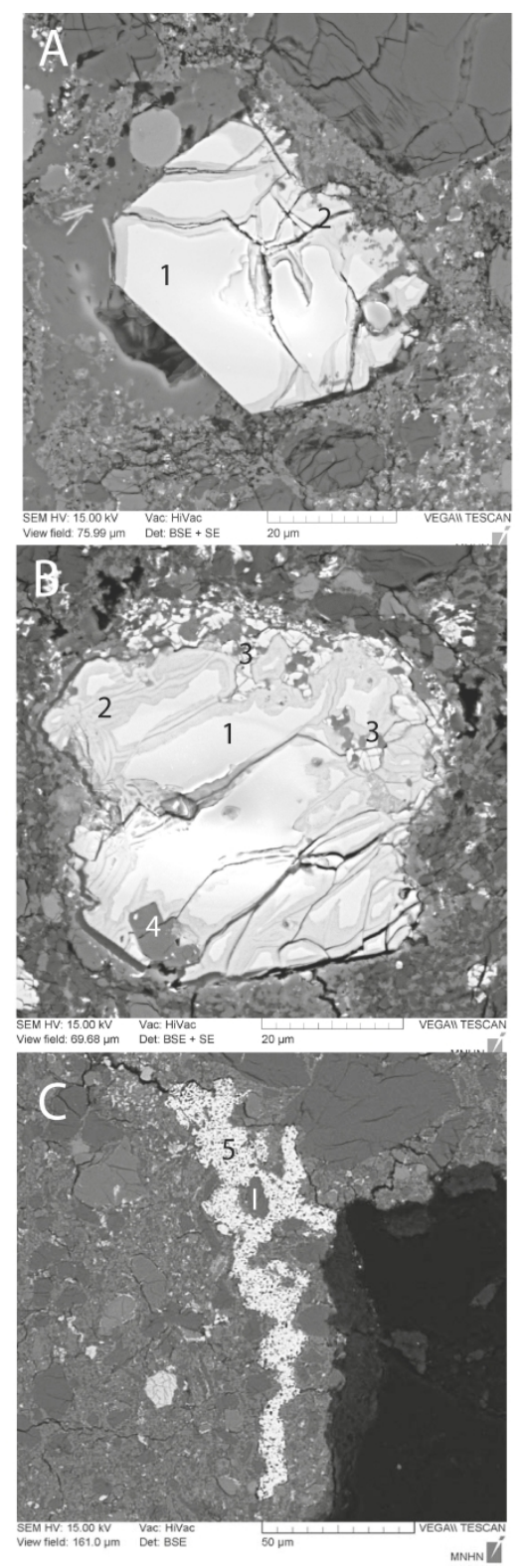

Fig. 1

$210 \times 297 \mathrm{~mm}(600 \times 600 \mathrm{DPI})$

Meteoritics \& Planetary Science 


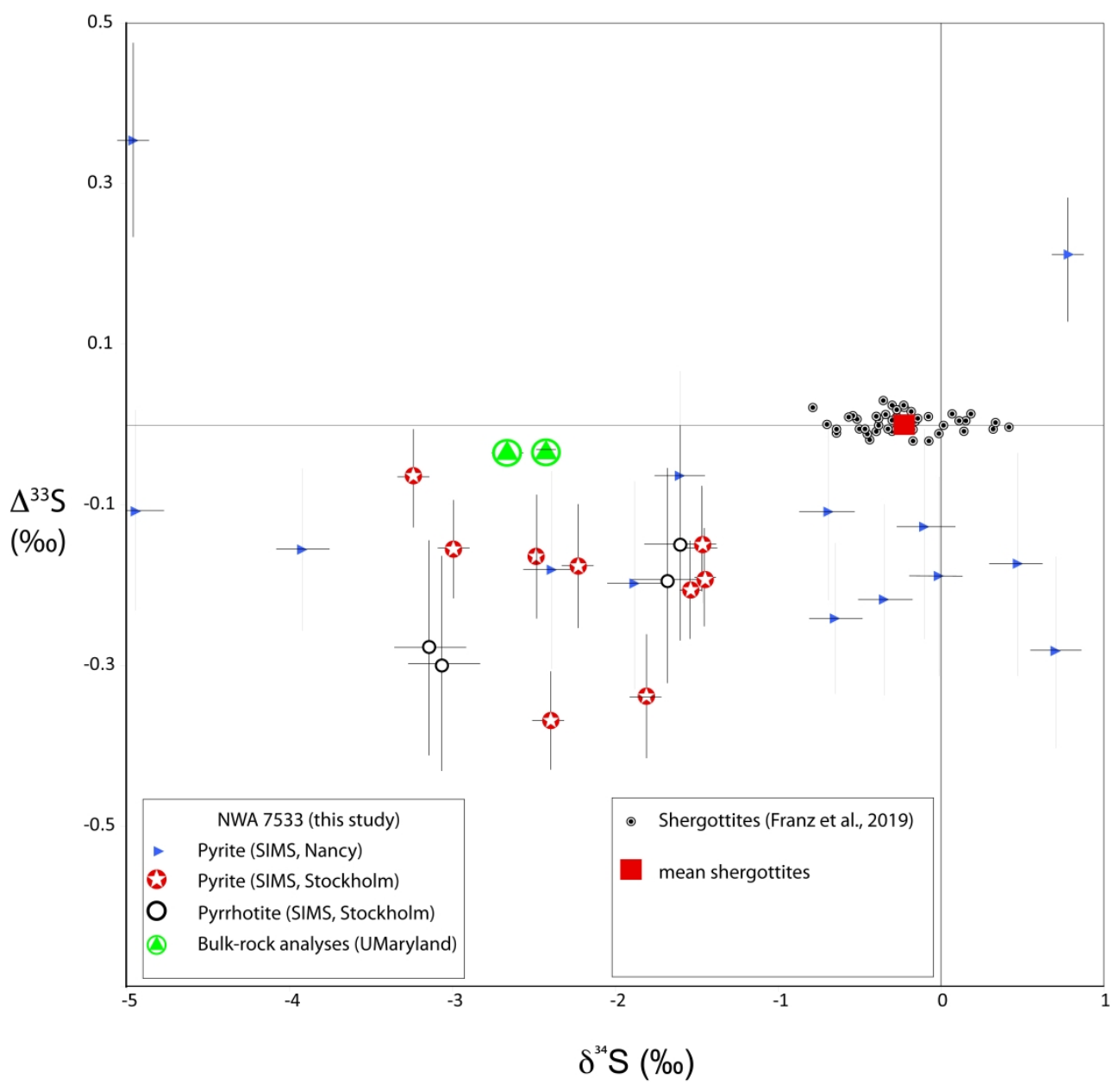

Fig. 2

$698 \times 855 \mathrm{~mm}(600 \times 600$ DPI $)$

Meteoritics \& Planetary Science 

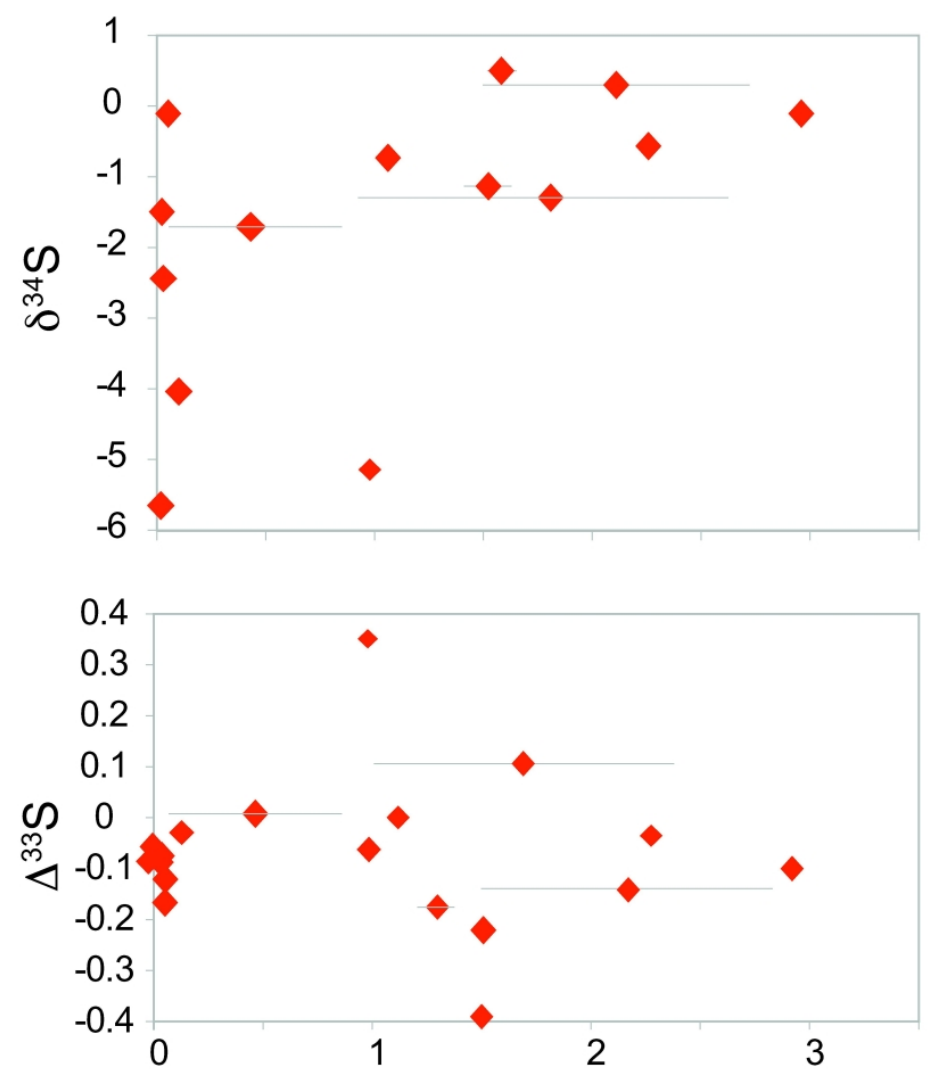

$\mathrm{Ni}$ (wt.\%)

Fig. 3 $228 \times 231 \mathrm{~mm}(600 \times 600$ DPI $)$ 


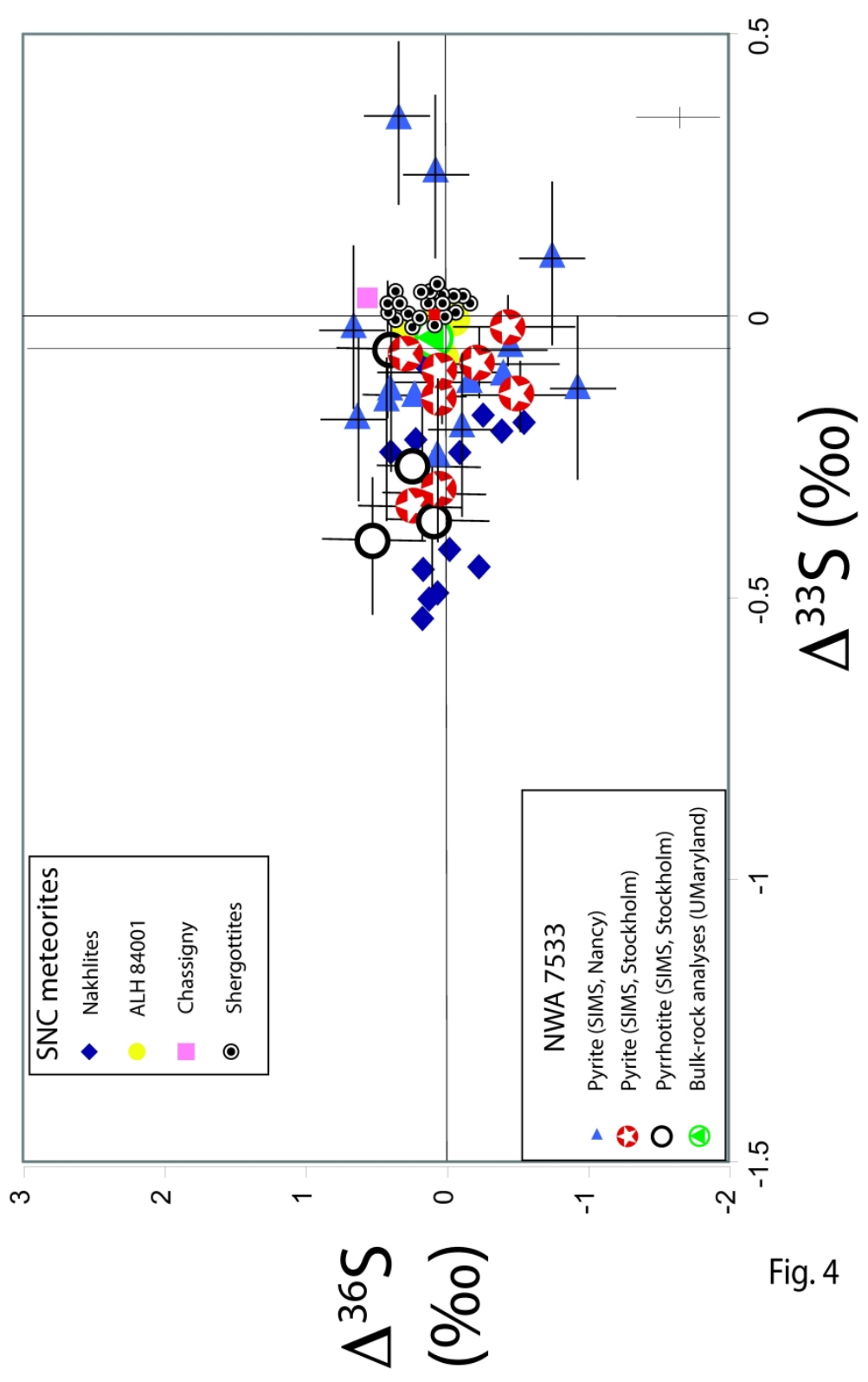

$188 \times 295 \mathrm{~mm}(600 \times 600 \mathrm{DPI})$ 


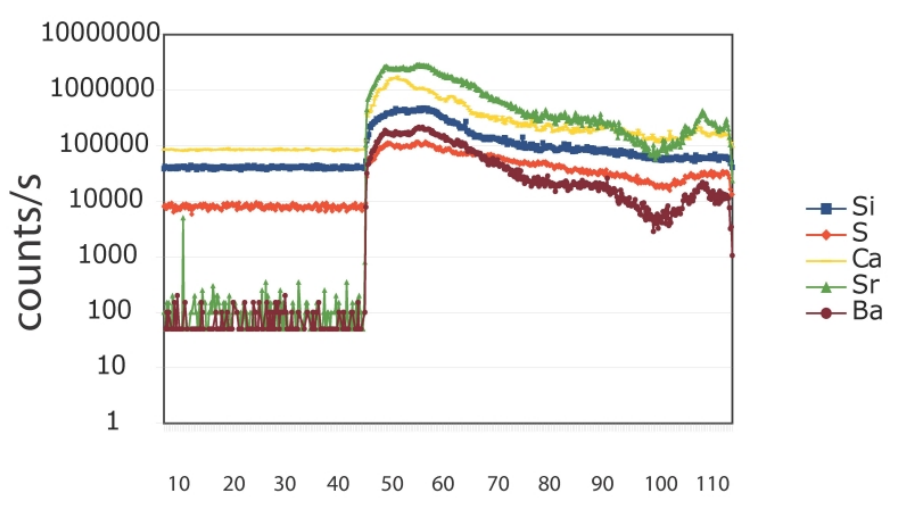

time (s)

Fig. 6

$210 \times 297 m m(600 \times 600$ DPI $)$

Meteoritics \& Planetary Science 


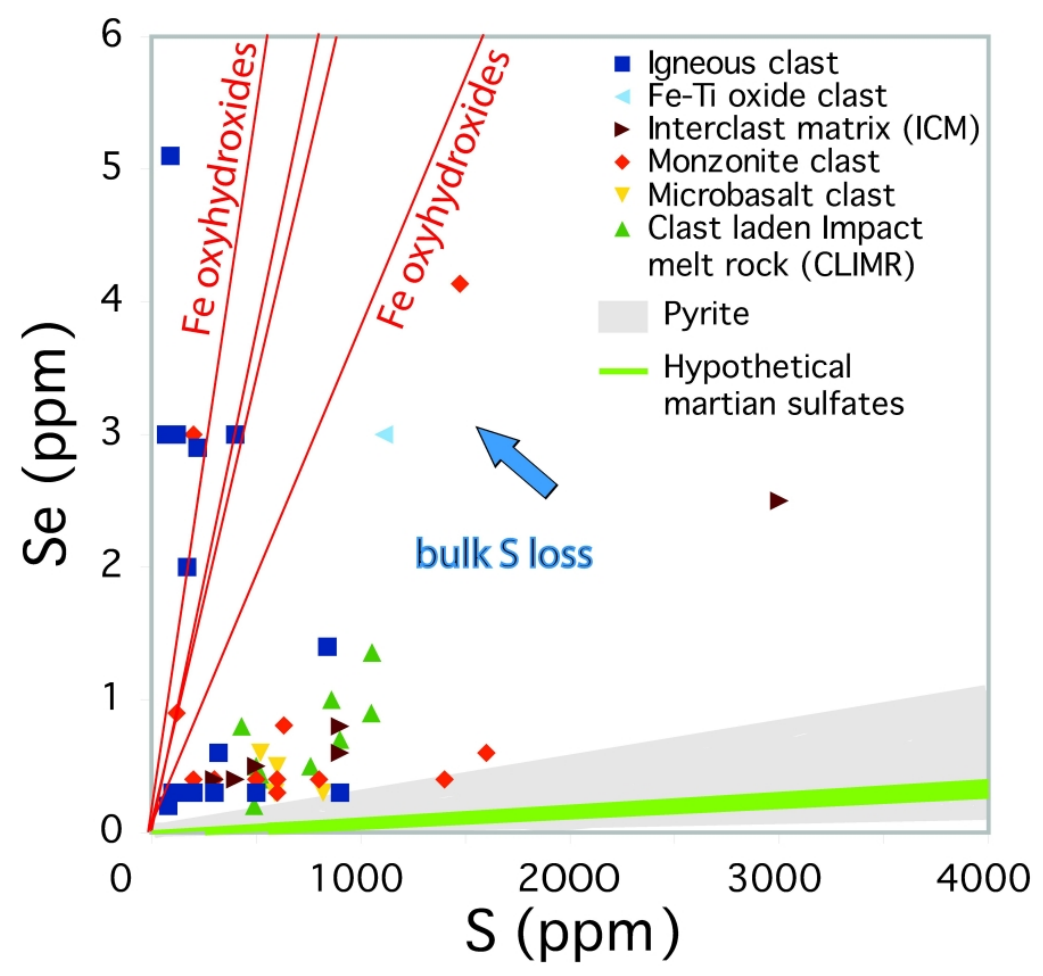

Fig. 5

$233 \times 252 \mathrm{~mm}(600 \times 600 \mathrm{DPI})$ 


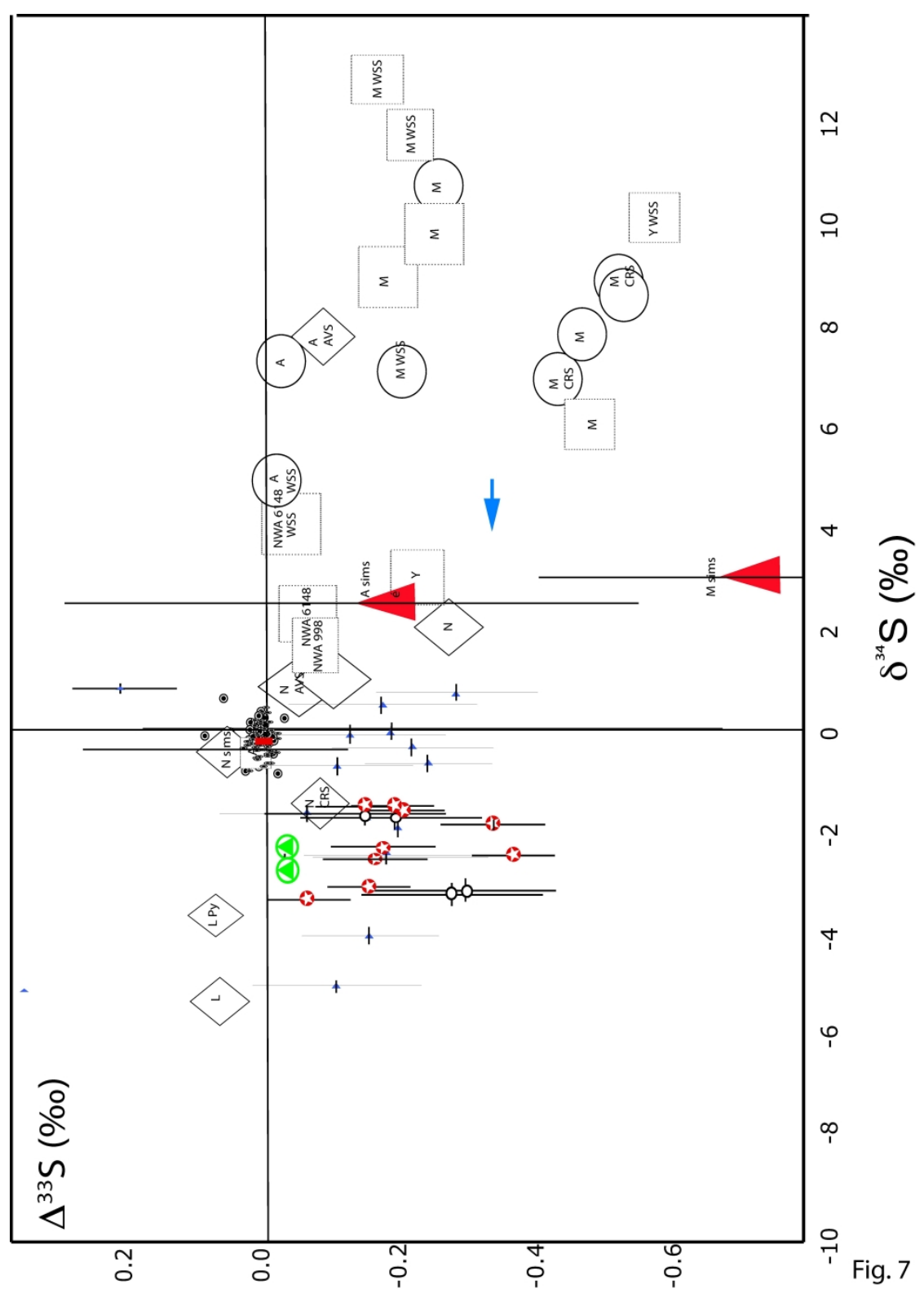

$211 \times 296 \mathrm{~mm}(600 \times 600 \mathrm{DPI})$

Meteoritics \& Planetary Science 
Table 1. S isotopic compositions of sulfides in NWA 7533 (Canon Diablo-normalized)

$$
\mathrm{S}\left(\mathrm{ppm}, \delta^{34} \mathrm{~S}(\%) \quad 2 \sigma \quad \Delta^{33} \mathrm{~S}(\%) \quad 2 \sigma \quad \mathrm{J}^{36} \mathrm{~S}(\%, \quad \mathbf{2 \sigma}\right.
$$

3ulk-rock (U Maryland)

$\begin{array}{cccccccc}\text { BB-UMD-1 } & 920 & -2.39 & 0.013 & -0.026 & 0.012 & 0.002 & 0.105 \\ \text { BB-UMD-2 } & 805 & -2.673 & 0.027 & -0.031 & 0.01 & 0.001 & 0.076 \\ \text { average } & \mathbf{8 6 3} & \mathbf{- 2 . 5 3 2} & \mathbf{0 . 0 1 5} & \mathbf{- 0 . 0 2 9} & \mathbf{0 . 0 1 0} & \mathbf{0 . 0 0 2} & \mathbf{0 . 0 9}\end{array}$

NWA 7533-4 (NORDSIMS)

$\begin{array}{ccccccc}\text { Site 8a Pyrite } & -1.82 & 0.23 & -0.34 & 0.17 & 0.08 & 0.53 \\ \text { Site 8b Pyrite } & -2.5 & 0.23 & -0.36 & 0.18 & 0.12 & 0.66 \\ \text { Site 5b Pyrite } & -1.54 & 0.18 & -0.21 & 0.12 & 0.03 & 0.44 \\ \text { Site 15 Pyrite } & -2.5 & 0.17 & -0.12 & 0.14 & 0.49 & 0.51 \\ \text { Site 16a Pyrite } & -1.63 & 0.17 & -0.21 & 0.14 & -0.55 & 0.53 \\ \text { Site 16b Pyrite } & -3.25 & 0.17 & -0.05 & 0.14 & -0.43 & 0.49 \\ \text { Site 17 Pyrite } & -2.99 & 0.18 & -0.16 & 0.13 & -0.004 & 0.45 \\ \text { Site b1a Pyrite } & -2.22 & 0.19 & -0.16 & 0.16 & -0.083 & 0.54 \\ \text { Site b1b Pyrite } & -1.5 & 0.17 & -0.13 & 0.14 & -0.39 & 0.53 \\ \text { Site 9a Pyrrhotite } & -1.65 & 0.38 & -0.19 & 0.28 & 0.12 & 0.81 \\ \text { Site 9bPyrrhotite } & -1.61 & 0.41 & -0.14 & 0.28 & 0.39 & 0.71 \\ \text { Site 11Pyrrhotite } & -3.16 & 0.4 & -0.26 & 0.3 & 0.05 & 0.6 \\ \text { Site 12Pyrrhotite } & -3.11 & 0.32 & -0.28 & 0.23 & 0.49 & 0.67 \\ \text { average } & \mathbf{- 2 . 2 2} & & \mathbf{- 0 . 1 8 6} & & \mathbf{0 . 0 1} & \\ \text { 2SD } & \mathbf{1 . 3 8} & & \mathbf{0 . 1 8} & & \mathbf{0 . 6 6} & \\ \text { wtd. Av. (95\% conf.) } & \mathbf{0 . 4 1} & & \mathbf{0 . 0 4 4} & & \mathbf{0 . 2 0} & \\ \text { MSWD } & \mathbf{4 2 .} & & \mathbf{1 . 1 1} & & \mathbf{1 . 4} & \end{array}$

NWA 7533-5 (Nancy).

Site A Pyrite

Site 8 Pyrite

Site -1a Pyrite

Site - $1 b$ Pyrite

Site -17 Pyrite

Site -19 Pyrite

Site -12 Pyrite

Site -C Pyrite

Site -6-1 Pyrite

Site 6-2 Pyrite

Site -B1 Pyrite

Site G Pyrite

Site -F-1 Pyrite

$\begin{array}{cccccc}-1.71 & 0.32 & -0.01 & 0.18 & 0.59 & 0.48 \\ 0.6 & 0.32 & -0.22 & 0.18 & 0.03 & 0.48 \\ -0.44 & 0.32 & -0.17 & 0.18 & 0.57 & 0.48 \\ -2.49 & 0.32 & -0.12 & 0.18 & 0.3 & 0.48 \\ -0.11 & 0.32 & -0.12 & 0.18 & 0.15 & 0.48 \\ 0.39 & 0.32 & -0.13 & 0.18 & 0.37 & 0.48 \\ -0.79 & 0.32 & -0.04 & 0.18 & -0.49 & 0.48 \\ -4.02 & 0.32 & -0.1 & 0.18 & -0.21 & 0.48 \\ -1.33 & 0.32 & 0.11 & 0.18 & -0.74 & 0.48 \\ -0.75 & 0.32 & -0.18 & 0.18 & -0.15 & 0.48 \\ -1.21 & 0.32 & -0.38 & 0.18 & -2.27 & 0.48 \\ -5.08 & 0.32 & -0.08 & 0.18 & -2.22 & 0.48 \\ -1.57 & 0.32 & -0.09 & 0.18 & -0.4 & 0.48\end{array}$




$\begin{array}{ccccccc}\text { Site -F-2 Pyrite } & -0.19 & 0.32 & -0.11 & 0.18 & -0.92 & 0.48 \\ \text { Site F-4 Pyrite } & -5.58 & 0.32 & 0.35 & 0.18 & 0.26 & 0.48 \\ \text { Site 16-1 Pyrite } & -2.01 & 0.32 & 0.24 & 0.18 & 0.02 & 0.48 \\ \text { average* } & \mathbf{- 1 . 6 5} & & \mathbf{- 0 . 1 2} & & \mathbf{0 . 3 2} & \\ \text { 2SD } & \mathbf{3 . 6 9} & & \mathbf{1 . 5} & & \mathbf{1 . 7 4} & \\ \text { wtd. av. (95\% conf.) } & \mathbf{0 . 9 8} & & \mathbf{0 . 0 6 4} & & \mathbf{0 . 4 6} & \\ \text { MSWD } & \mathbf{1 3 2} & & \mathbf{1 . 5} & & \mathbf{1 3 . 0} & \end{array}$

* : exclude the positive values of $\Delta 33$ S in Site F-4 Pyrite and Site 16-1 Pyrite

2SD is the simple $2 \mathrm{x}$ standard deviation on the values (measures variation in a data set regard wtd.av. is the weighted average uncertainty on the data along its MSWD value (measures the 
lless of individual run uncertainties);) ə spread) 
Table 2. Laser Ablation inductively-coupled mass spectrometry (LA-ICPMS) analyses of pyrite alteration products.

Fe oxyhydroxides (pyrite alteration products)

\begin{tabular}{|c|c|c|c|c|c|c|}
\hline $\begin{array}{c}1 \\
\text { LA- } \\
\text { ICPMS }\end{array}$ & $\begin{array}{c}2 \\
\text { LA- } \\
\text { ICPMS }\end{array}$ & $\begin{array}{c}3 \\
\text { LA- } \\
\text { ICPMS }\end{array}$ & $\begin{array}{c}4 \\
\text { LA- } \\
\text { ICPMS }\end{array}$ & $\begin{array}{c}5 \\
\text { LA- } \\
\text { ICPMS }\end{array}$ & $\begin{array}{c}6 \\
\text { LA- } \\
\text { ICPMS }\end{array}$ & $\begin{array}{c}\text { EMPA } \\
(n=15)^{*}\end{array}$ \\
\hline 2392 & 2059 & 3061 & 4128 & 3728 & 2299 & $2400+/-130$ \\
\hline 4455.5 & 13158.6 & 10681.2 & 5349.9 & 11609.4 & 8009.6 & $9500+/-20$ \\
\hline 79.5 & 75.6 & 372.3 & 386.2 & 411.3 & 283.4 & \\
\hline 227.1 & 91.1 & 198.2 & 283.6 & 271.6 & 233.6 & \\
\hline
\end{tabular}

detection limits

$\mathrm{S}(\mathrm{ppm})$

$\begin{array}{cccccc}2.83 & 3.09 & 4.48 & 4.14 & 7.76 & 3.77 \\ 3.68 & 4.17 & 6.20 & 5.82 & 11.20 & 5.81 \\ 0.001 & 0.001 & 0.002 & 0.002 & 0.004 & 0.002 \\ 0.009 & 0.009 & 0.014 & 0.013 & 0.027 & 0.014 \\ 0.003 & 0.003 & 0.005 & 0.005 & 0.010 & 0.004\end{array}$

Apatite

$\mathrm{S}$ (ppm)

$\mathrm{Ca}$

$\mathrm{Sr}$

1

$\mathrm{Ca}$

$\mathrm{Sr}$

1
LA-
ICPMS

46

6

LA-
ICPMS

ICPMS

7

LA-

229.9

230.2

209.3

ICPMS

IS IS

IS

217.2

IS

137.3

157.6

145.6

112.7

8

LA-

ICPMS

LA

6.73

8.98

8.05

5.09

229.6

IS

179.9

179.9
7.28

9

ICPMS

231.1

IS

197.7

12.4

10

detection limits

S (ppm)

$\begin{array}{ll}2.01 & 2.81 \\ 0.001 & 0.001 \\ 0.006 & 0.009\end{array}$

2.40

3.37

3.10

3.42

3.87

$\mathrm{Sr}$

0.001

0.001

0.009

0.007

0.009

0.008

0.001

0.009

LA-ICPMS 267.6

IS

143.9

5.13

*Electron Microprobe analyses-EMPA (Lorand et al., 2015) ; IS = Internal Standard. 